Prepared in cooperation with the St. Johns River Water Management District

\title{
Using Heat as a Tracer to Determine Groundwater Seepage in the Indian River Lagoon, Florida, April-November 2017
}

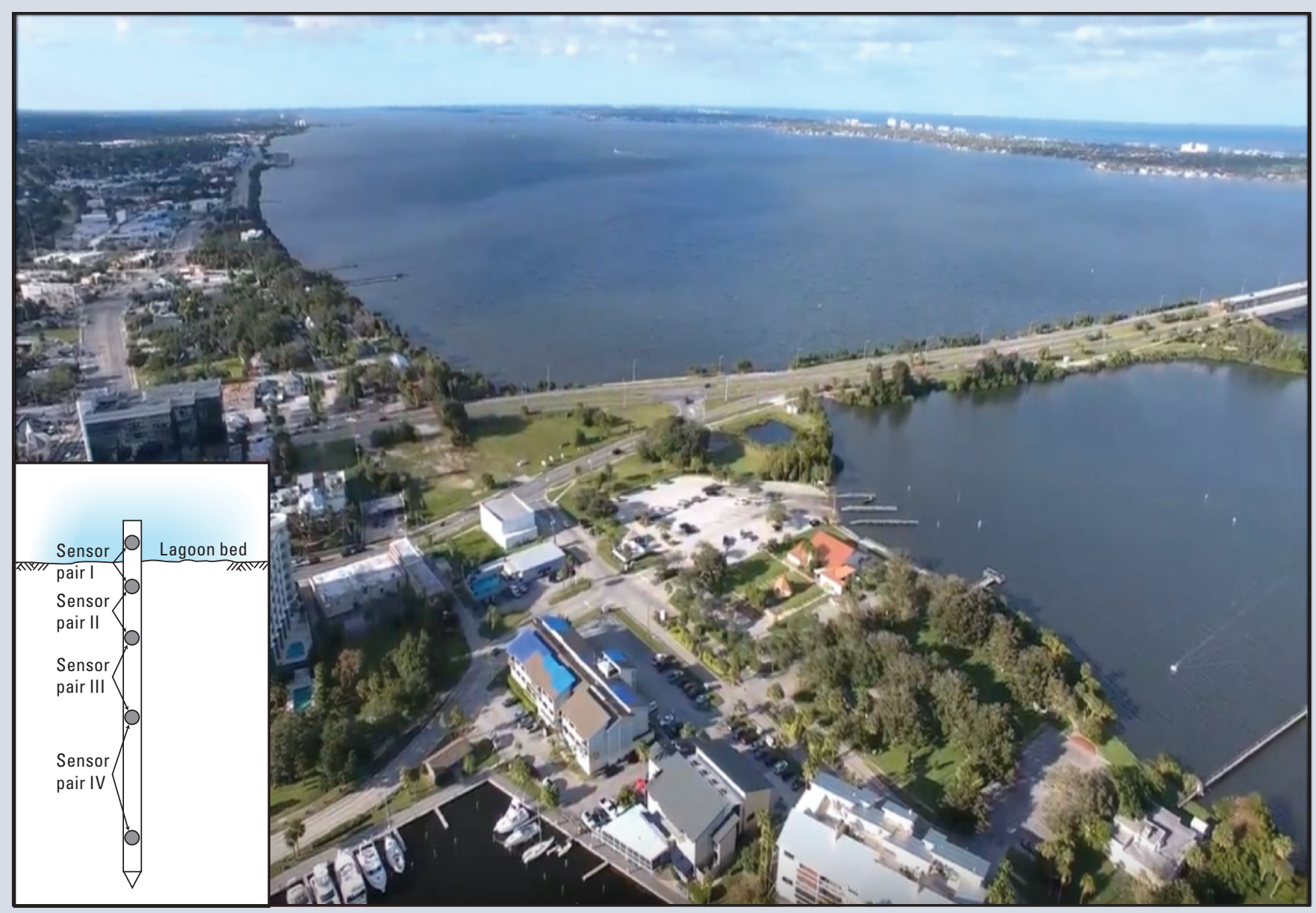

Open-File Report 2018-1151 
Cover. Photograph showing Indian River Lagoon looking north towards Eau Gallie, Florida. Photograph by Flights Over Florida, used with permission. Inset diagram showing vertical profile of a temperature sensor used in this study. Further details shown in figure 2 herein. 


\section{Using Heat as a Tracer to Determine Ground water Seepage in the Indian River Lagoon, Florida, April-November 2017}

By Eric D. Swain and Scott T. Prinos

Prepared in cooperation with the St. Johns River Water Management District

Open-File Report 2018-1151 


\section{U.S. Department of the Interior \\ RYAN K. ZINKE, Secretary}

\section{U.S. Geological Survey James F. Reilly II, Director}

\section{U.S. Geological Survey, Reston, Virginia: 2018}

For more information on the USGS - the Federal source for science about the Earth, its natural and living resources, natural hazards, and the environment-visit https://www.usgs.gov or call 1-888-ASK-USGS.

For an overview of USGS information products, including maps, imagery, and publications, visit https://store.usgs.gov.

Any use of trade, firm, or product names is for descriptive purposes only and does not imply endorsement by the U.S. Government.

Although this information product, for the most part, is in the public domain, it also may contain copyrighted materials as noted in the text. Permission to reproduce copyrighted items must be secured from the copyright owner.

Suggested citation:

Swain E.D., and Prinos, S.T., 2018, Using heat as a tracer to determine groundwater seepage in the Indian River Lagoon, Florida, April-November, 2017: U.S. Geological Survey Open-File Report 2018-1151, 18 p., https://doi.org/10.3133/ofr20181151.

ISSN 2331-1258 (online) 


\section{Acknowledgments}

The authors would like to acknowledge the contribution of U.S. Geological Survey personnel Allison Bauser, Jeremy Decker, Jacob Russell, Dorothy Sifuentes, and David Sumner in the installation of the field measurement sites and Martin Briggs for his advice and guidance in the computational modeling. 



\section{Contents}

Acknowledgments ......................................................................................................................ii

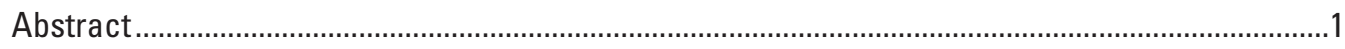

Introduction

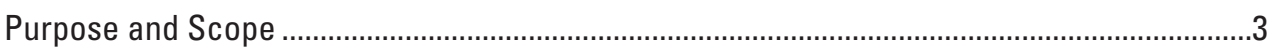

Geography and Hydrogeology of the Indian River Lagoon ...................................................

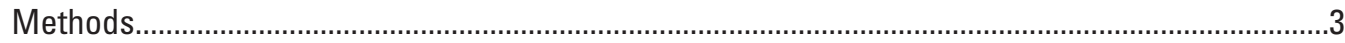

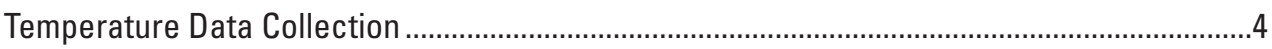

Computation of Groundwater Seepage .........................................................................

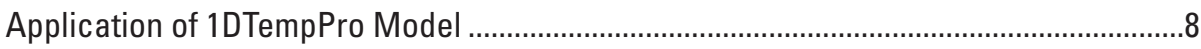

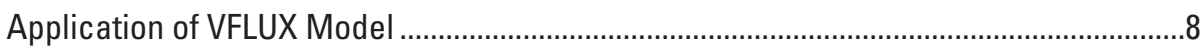

Estimation of Groundwater Seepage Exchange With Lagoon Surface Water.................................10

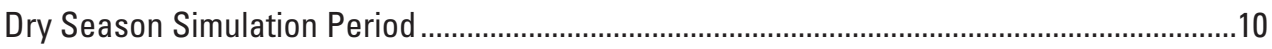

Estimating Flux for Locations Lacking A Surface-Water Sensor......................................11

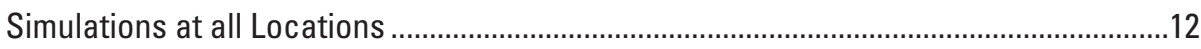

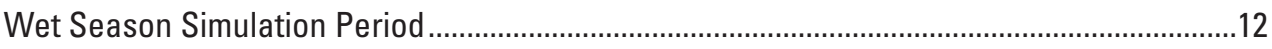

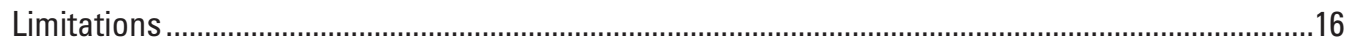

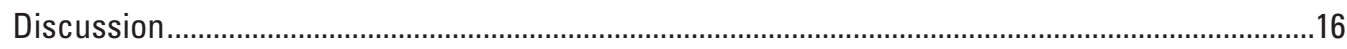

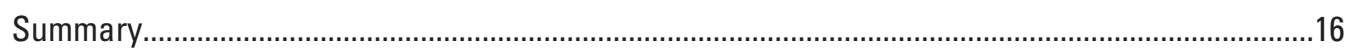

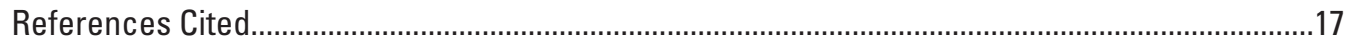

\section{Figures}

1. Maps showing the location of the Indian River Lagoon, and the Eau Gallie and Rockledge study areas in Brevard County, Florida ...........................................................2

2. Schematic showing the vertical profile of a temperature sensor used in this study

3. Aerial photograph showing temperature sensor locations at the Eau Gallie study area during March 23-April 28, 2017.

4. Aerial photograph showing temperature sensor locations at the Eau Gallie study area during June 1-November 3, 2017.

5. Graph showing measured temperatures at various depths for location $1 \mathrm{~A}$ in the Eau Gallie study area ........................................................................................................

6. Graph showing 1DTempPro and VFLUX results at location 1A in the Eau Gallie study area, March-April 2017.

7. Scatterplots showing average flux values from the highest three sensor pairs and flux values from the highest sensor pair beneath the lagoon bed in the Eau Gallie study area, March-April 2017

8. Graph showing computed seepage flux in the Eau Gallie study area, March-April 2017...

9. Graph showing average seepage flux and distance offshore in the Eau Gallie study area, March 24-April 20, 2017.

10. Scatterplots showing flux computed from top three sensor pairs and highest sensor pair beneath the lagoon bed in the Eau Gallie study area for June 1-September 9, 2017, and September 11-November 3, 2017. 
11. Graph showing computed seepage flux in the Eau Gallie study area, June-October 2017.

12. Graph showing relation between average seepage flux and distance offshore in the Eau Gallie study area, June 20-July 20, 2017.

\section{Tables}

1. Derived coefficients for linear fit equation for March 24-April 28, 2017, temperature data

2. Derived coefficients for linear fit equation for June 1-November 3, 2017, temperature data

\section{Conversion Factors}

[International System of Units to U.S. customary units]

\begin{tabular}{lcl}
\hline \multicolumn{1}{c}{ Multiply } & By & \multicolumn{1}{c}{ To obtain } \\
\hline centimeter $(\mathrm{cm})$ & Length & inch (in.) \\
millimeter $(\mathrm{mm})$ & 0.3937 & inch (in.) \\
meter $(\mathrm{m})$ & 0.03937 & foot (ft) \\
kilometer $(\mathrm{km})$ & 3.281 & mile (mi) \\
\hline & 0.6214 & acre \\
\hline hectare $($ ha) & Area & square mile $\left(\mathrm{mi}^{2}\right)$ \\
square kilometer $\left(\mathrm{km}^{2}\right)$ & 2.471 & \\
\hline & 0.3861 & kilowatthour $(\mathrm{kWh})$ \\
\hline joule $(\mathrm{J})$ & Energy & foot per day $(\mathrm{ft} / \mathrm{d})$ \\
\hline
\end{tabular}

Temperature in degrees Celsius $\left({ }^{\circ} \mathrm{C}\right)$ may be converted to degrees Fahrenheit $\left({ }^{\circ} \mathrm{F}\right)$ as follows:

${ }^{\circ} \mathrm{F}=\left(1.8 \times{ }^{\circ} \mathrm{C}\right)+32$.

Temperature in degrees Fahrenheit $\left({ }^{\circ} \mathrm{F}\right)$ may be converted to degrees Celsius $\left({ }^{\circ} \mathrm{C}\right)$ as follows:

$$
{ }^{\circ} \mathrm{C}=\left({ }^{\circ} \mathrm{F}-32\right) / 1.8 .
$$

\section{Abbreviations}

IRL Indian River Lagoon

PVC polyvinyl chloride 


\title{
Using Heat as a Tracer to Determine Groundwater Seepage in the Indian River Lagoon, Florida, April- November 2017
}

\author{
By Eric D. Swain and Scott T. Prinos
}

\section{Abstract}

The U.S. Geological Survey, in cooperation with the St. Johns River Water Management District, conducted a study to examine water fluxes in two small study areas in the Indian River Lagoon. Vertical arrays of temperature sensors were placed at multiple locations in the lagoon bed to measure temperature time series in the vertical profile. These data at one of the study areas, Eau Gallie, were used in two numerical models, 1DTempPro and VFLUX, to estimate seepage flux rates into the lagoon. 1DTempPro uses an inverse-modeling approach to calibrate groundwater flux to the measured temperature time series. VFLUX isolates the fundamental frequency signal in the temperature data and utilizes the resulting amplitude and phase differences between sensor locations to determine vertical water flux.

Field measurements were made during two time periods, March 23 to April 28, 2017, and June 1 to November 3, 2017. Simulating the first, drier period at one location with 1DTempPro helped determine reasonable seepage fluctuations and provided guidelines for choosing which temperature sensor pairs used in the VFLUX simulations would produce the best results. VFLUX simulations at eight locations indicated daily average seepage flux rates of less than 20 centimeters per day $(\mathrm{cm} / \mathrm{d})$ and substantial seepage flux out to a distance of at least 110 meters from shore. The spatial variation in average seepage flux rates within 40 meters of shore seemed large, ranging from about 3 to $20 \mathrm{~cm} / \mathrm{d}$.

In the VFLUX application using the June 1-November 3, 2017 data, the seepage flux has a higher magnitude and fluctuation than the first simulation period, making the isolation of the fundamental temperature frequency signal in the temperature data difficult. However, useful partial or full simulations were achieved at 6 of the 10 locations. The storm surge of Hurricane Irma on September 10, 2017, changed the depths of the sensors relative to the lagoon bed and disrupted the ability of VFLUX to compute seepage flux for the posthurricane period. The June 1 to November 3, 2017, computed seepage flux rates were higher than those for the March 24 to April 28, 2017, period and were sometimes as great as $40 \mathrm{~cm} / \mathrm{d}$, and more than $60 \mathrm{~cm} / \mathrm{d}$ at one location. The seepage time-series data collected during Hurricane Irma indicates a downward seepage flux as a result of the storm surge, followed by upwelling from precipitation recharge inland. The average seepage flux rates are higher than those during the March-April period and are over $25 \mathrm{~cm} / \mathrm{d}$ near the coast and about $20 \mathrm{~cm} / \mathrm{d} 130$ meters offshore.

\section{Introduction}

The Indian River Lagoon (IRL) in east-central Florida is one of 28 "Estuaries of National Significance," as designated by the U.S. Congress (fig. 1; Indian River Lagoon National Estuary Program, 2018). Phytoplankton blooms have occurred in the lagoon and resulted in decreased water transparency, increased light attenuation, and widespread seagrass loss (St. Johns River Water Management District and others, 2012), as well as die-offs of fish and other aquatic species. One of the largest blooms occurred in 2011 and resulted in a decrease in seagrass extent from about 32,000 hectares in 2009 to 18,600 hectares in 2011 (Indian River Lagoon National Estuary Program, 2018). The cause of the blooms is being investigated by various Federal, State, local, and private organizations. One potential factor contributing to degradation of the lagoon's water quality is the seepage of effluent from septic systems (Barile, 2018). The flux of groundwater into the lagoon, transporting the contaminating effluent, can be estimated by measuring vertical temperature profiles in sediments beneath the lagoon bed.

Vertical profiles of temperature in sediments beneath water bodies have been used to infer the vertical exchange of groundwater and surface water (Irvine and others, 2017). Diurnal oscillations in the temperature of a water body tend to propagate downward into the underlying sediments by means of conduction. Downward fluxes of water into the sediments transport the diurnal temperature signal deeper into the sediments through advection than would be expected by conduction alone. Conversely, upward fluxes of water from the sediments into the water body lead to more temperature 


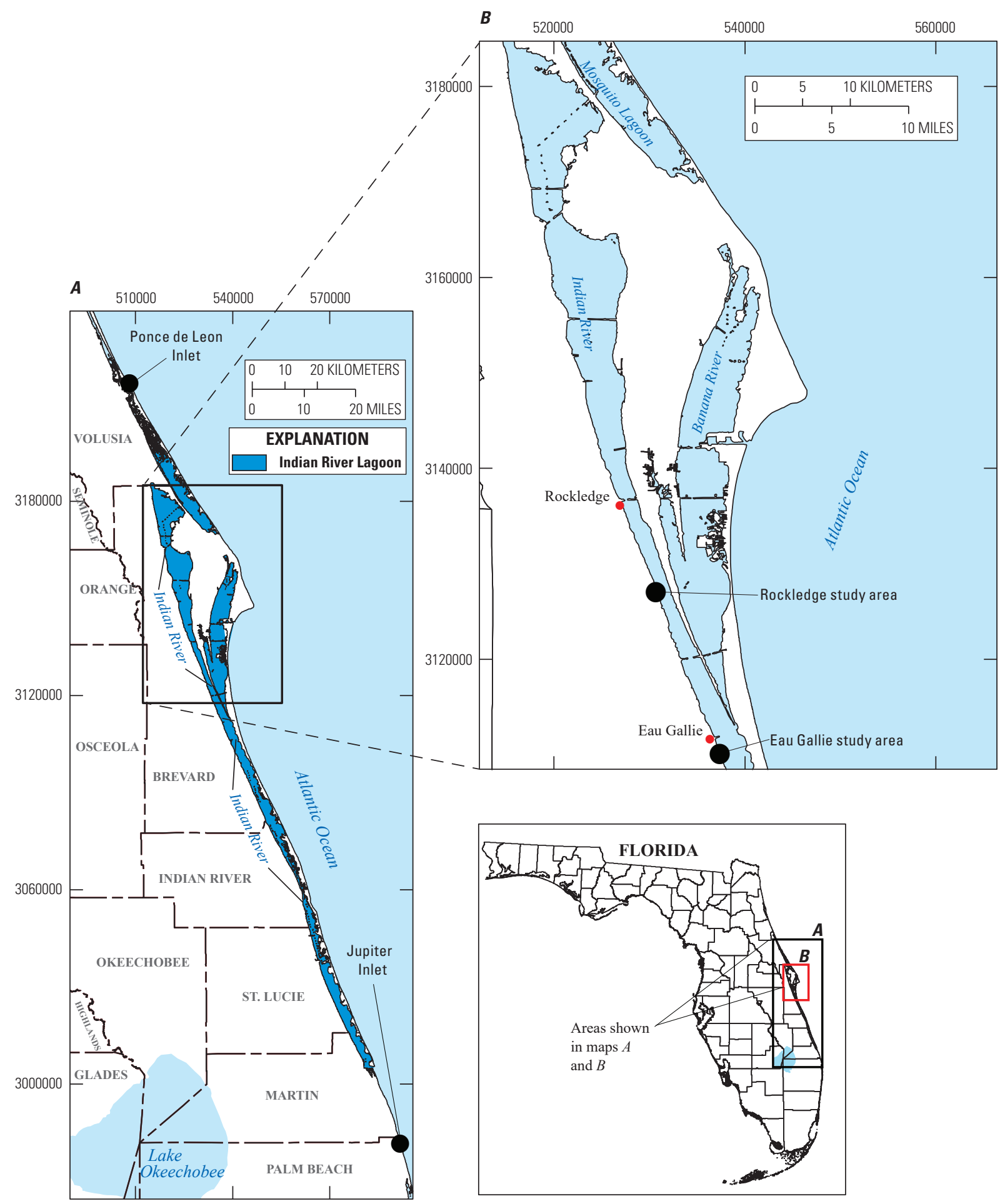

Base from ArcGIS Map Service, University of Florida Geoplan Center and U.S. Geological Survey digital data. Projection, Universal Transverse Mercator, North American Datum of 1983, Zone 17 North

Figure 1. Location of, $A$, the Indian River Lagoon, and $B$, the Eau Gallie and Rockledge study areas in Brevard County, Florida. The Indian River Lagoon consists of Indian River, Banana River, and Mosquito Lagoon. 
signal attenuation with sediment depth than would be expected via conduction (Irvine and others, 2017). Vertical temperature profiles collected over time can be modeled to determine the vertical fluxes of water into or out of the water body in the sediment zones of interest. The U.S. Geological Survey, in cooperation with the St. Johns River Water Management District, conducted a study in 2017 to examine water fluxes in two small study areas in the IRL: one near Eau Gallie, Florida, and the other near Rockledge, Fla. (fig. 1).

The data collected in the Eau Gallie study area was chosen to apply a proof-of-concept approach regarding the use of heat as a tracer of vertical water exchange that may provide information about the relative scale of groundwater contributions to the lagoon. The Eau Gallie study areas is small relative to the size of the IRL, so this analysis cannot be used alone to evaluate the total groundwater contribution to the IRL. However, this is a first step in direct estimation of groundwater contributions to the IRL, and thus the potential for groundwater transport of nutrients.

\section{Purpose and Scope}

The purpose of this report is to (1) document the procedures used to collect vertical temperature profiles in sediments beneath the IRL, and (2) describe the modeling of these data to evaluate water fluxes into and out of the IRL in the Eau Gallie study area. This report includes discussions of the geography and hydrogeology of the IRL, the design of the temperature profiling stakes used to collect the data, the quality assurance of these data, and the analysis of the data from the Eau Gallie study area. The modeling and analysis of data are limited to those data collected from the Eau Gallie study area, which provided the most complete data available for analysis. Included in this report are estimates of upward and downward fluxes of water into and out of the lagoon at multiple locations and (or) distances from shore in the Eau Gallie study area.

\section{Geography and Hydrogeology of the Indian River Lagoon}

The IRL is an estuarine system consisting of three lagoons, namely the Banana River, the Indian River, and the Mosquito Lagoon (fig. 1B). The brackish estuary is 251 kilometers long, 2.5 to 8 kilometers wide, and extends from northern Brevard County to the southern boundary of Martin County (fig. 1A; St. Johns River Water Management District, 2007). The IRL covers 568 square kilometers and has an average depth of 1.2 meters (m) (St. Johns River Water Management District, 2018). Water from the IRL and Atlantic Ocean mix through five ocean inlets. The salinity of the IRL is controlled by the exchange of water through these inlets, as well as precipitation, wind, tidal forcing, evaporation, surface runoff, and potential submarine groundwater discharge (Swarzenski and others, 2000).
The sediments of the IRL overlie the Pleistocene-age Anastasia Formation (Scott, 1993). The Anastasia Formation is

“. . . composed of interbedded sands and coquinoid limestones. The most recognized facies of the Anastasia sediments is an orangish brown, unindurated to moderately indurated, coquina of whole and fragmented mollusk shells in a matrix of sand often cemented by sparry calcite. Sands occur as light gray to tan and orangish brown, unconsolidated to moderately indurated, unfossiliferous to very fossiliferous beds" (U.S. Geological Survey, 2016).

The bottom of the lagoon at the Eau Gallie study area (fig. $1 B$ ) consists mostly of fine sand. Quantitative analyses of sediment samples collected near the Eau Gallie study area were conducted by Trefry and Trocine (2011), but no sediment samples were collected within the study area.

\section{Methods}

Temperature measurements have been used to estimate heat transport, and by extension water flux, in groundwater systems since the 1960s (Anderson, 2005). These applications include the use of temperature to evaluate vertical groundwater seepage flux in fluvial environments, where surface water directly overlies groundwater (Hatch and others, 2006; Keery and others, 2007; Vogt and others, 2010). Seepage may be discharge from groundwater to overlying surface water (upward flux) or recharge from surface water to groundwater (downward flux). Direct physical measurement of groundwater seepage is prone to large uncertainty because of the difficulty in access and flow detection in a porous media located beneath a surface-water body. Seepage flux measurements can involve embedded devices that directly measure fluid flow or indirect resistivity methods that determine flow locations by means of salinity measurements. The installation of such a device disturbs the seepage media and may influence the flow system. Tracer studies are useful, but the application of an artificial tracer is logistically intensive in an embayment and difficult to constrain. Using naturally occurring heat as a tracer has the advantage of simplified logistics and instrumentation but is limited by the ability of the sensors to resolve ambient temperature gradients and the assumption of purely vertical flow.

Locations where temperature variations may indicate groundwater seepage can be identified by using fiber-optic, distributed temperature-sensing surveys (Briggs and others, 2012). During these surveys, pulses of light are transmitted through a fiber-optic cable, and the ratio of temperature-independent Raman backscatter (Stokes) to temperature-dependent backscatter (anti-Stokes) of the light pulse is measured. A spatially distributed temperature map is 
generated, yielding information that can be used to position temperature probes in order to determine seepage flux (Rosenberry and others, 2016).

The determination of seepage flux using temperature can be defined as an inverse problem, where mass advection is estimated by matching calculated temperatures to observed temperatures. Temperature profiles in beds that underlie surface-water bodies can be related to seepage flux as in any other groundwater-flow environment, and even the shape of the vertical temperature profile (concave or convex) can be used to infer whether the flux is upward from the groundwater to surface water or downward from the surface water to groundwater (Bredehoeft and Papadopulos, 1965).

Realistic estimates of heat-transport and groundwater flow parameters are needed to accurately estimate seepage flux from measured temperature data. Ideally, such estimates are obtained through analysis of the actual sediment, although estimates of heat capacity and conductance have been standardized for many soil materials (Arya, 2001). Increased temperature difference between surface water and groundwater reduces uncertainty in groundwater flux estimates obtained by means of heat tracer studies/experiments, and areas having larger annual temperature fluctuations tend to have larger spatial gradients in temperatures and are more conducive to heat-tracer applications (Lapham, 1989). The IRL does not experience large fluctuations in annual temperature compared to those of lagoons in temperate-zone regions, where many studies have successfully used heat to estimate groundwater seepage flux, but existing differences in inland and offshore water temperatures made the analysis presented herein possible.

The two models chosen for this study use the method of inverse modeling of mass advection from the temperature-profile time series and the method of determining mass flux from vertical propagation of temperature signals over time. These models both rely on the measured temperature data from probes imbedded in the lagoon bed, described next.

\section{Temperature Data Collection}

Vertical temperature profiles in the sub-bottom of the IRL were collected using 4 to 5 DS1922L-F5 Thermochron iButton temperature sensors imbedded in 0.6- to 0.9-m-long polyvinyl chloride (PVC) stakes designed to be driven into the bottom of the lagoon (fig. 2). These temperature sensors have an accuracy of $\pm 0.5^{\circ} \mathrm{C}$ within the temperature range of -10 to $+65^{\circ} \mathrm{C}$ and were programmed to record temperatures hourly at a precision of $0.0625^{\circ} \mathrm{C}$. The memory storage in each temperature sensor can store 4,096 data values at this precision. To house the temperature sensors, flat-bottomed pockets that were 1 centimeter $(\mathrm{cm})$ deep by $2 \mathrm{~cm}$ in diameter were drilled in each stake, perpendicular to its axis. The sensors were programmed prior to installation, placed in the pockets in the stakes, and covered with clear silicone caulking to seal them from the water of the lagoon. The stake was wrapped with 20-millimeter-thick PVC pipe-wrap tape at the location of each sensor to provide additional protection. It has been previously shown that wrapping of this magnitude does not substantially impact the measurement of ambient sediment temperature (Cardenas, 2010). A reference mark was placed on each stake, indicating ground level, and the stakes were driven into the bottom of the lagoon to the depth of this mark.

Temperature data was taken during two time periods in the Eau Gallie area. Eight sensor stakes were installed for the period of March 23-April 28, 2017, denoted by a number and the letter A (fig. 3), and 10 sensor stakes were installed for the period of June 1-November 3, 2017, denoted by a number and the letter B (fig. 4). Similar data collection was also made at Rockledge (fig. 1), but this study only focuses on the Eau Gallie area and the application of the measured temperature data to the simulation of seepage flux.

The first temperature profile data (Prinos and Briggs, 2017) from eight sensor stakes deployed in the Eau Gallie study area on March 23, 2017, and retrieved on April 28, 2017 (fig. 3), involved the testing of two different stake designs. This initial deployment revealed that the diurnal temperature signal was weak at a depth of $63.5 \mathrm{~cm}$. None of the sensors failed during this testing. Given the results of this first deployment of temperature sensor stakes, the two 0.9 -m-long stakes were shortened to $0.6 \mathrm{~m}$, which eliminated the sensor at $63.5 \mathrm{~cm}$. An additional sensor was added at a depth of $5.1 \mathrm{~cm}$ for the second deployment (fig. 4).

As part of this study, fiber-optic-distributed temperature sensing surveys were conducted at the Eau Gallie study area during May 25-30, 2017 (Prinos and Briggs, 2017). Given the results of these surveys, 10 sensor stakes were installed for the second deployment at Eau Gallie on June 1, 2017, and removed November 2-3, 2017.

After they were collected from the field, the temperature profiling stakes were placed in an ice bath to check the accuracy of the sensors. All of the data collected from sensors within the ice bath were within the stated accuracy of the sensors, so no temperature corrections were required. Some of the sensors that provided partial record stopped recording for a period and then restarted. The ice bath provided a good date-time reference, so whenever possible, blocks of data were aligned using this reference. Some of the partial data could not be aligned using this reference because of multiple gaps in the record.

To test computational methods to determine water flux rates from changes in the vertical profile of the water temperature, the data collected at Eau Gallie from March 23 to April 28, 2017 (fig. 3) and from June 1 to November 3, 2017 (fig. 4) (hereafter referred to as March-April and June-November, respectively) at depths ranging from $5.1 \mathrm{~cm}$ above to $36.8 \mathrm{~cm}$ below the bed surface (fig. 2) were used. The diurnal fluctuations in temperature are well defined in the measurements and can be used to define the effects of advection, which can be used to infer flux. 


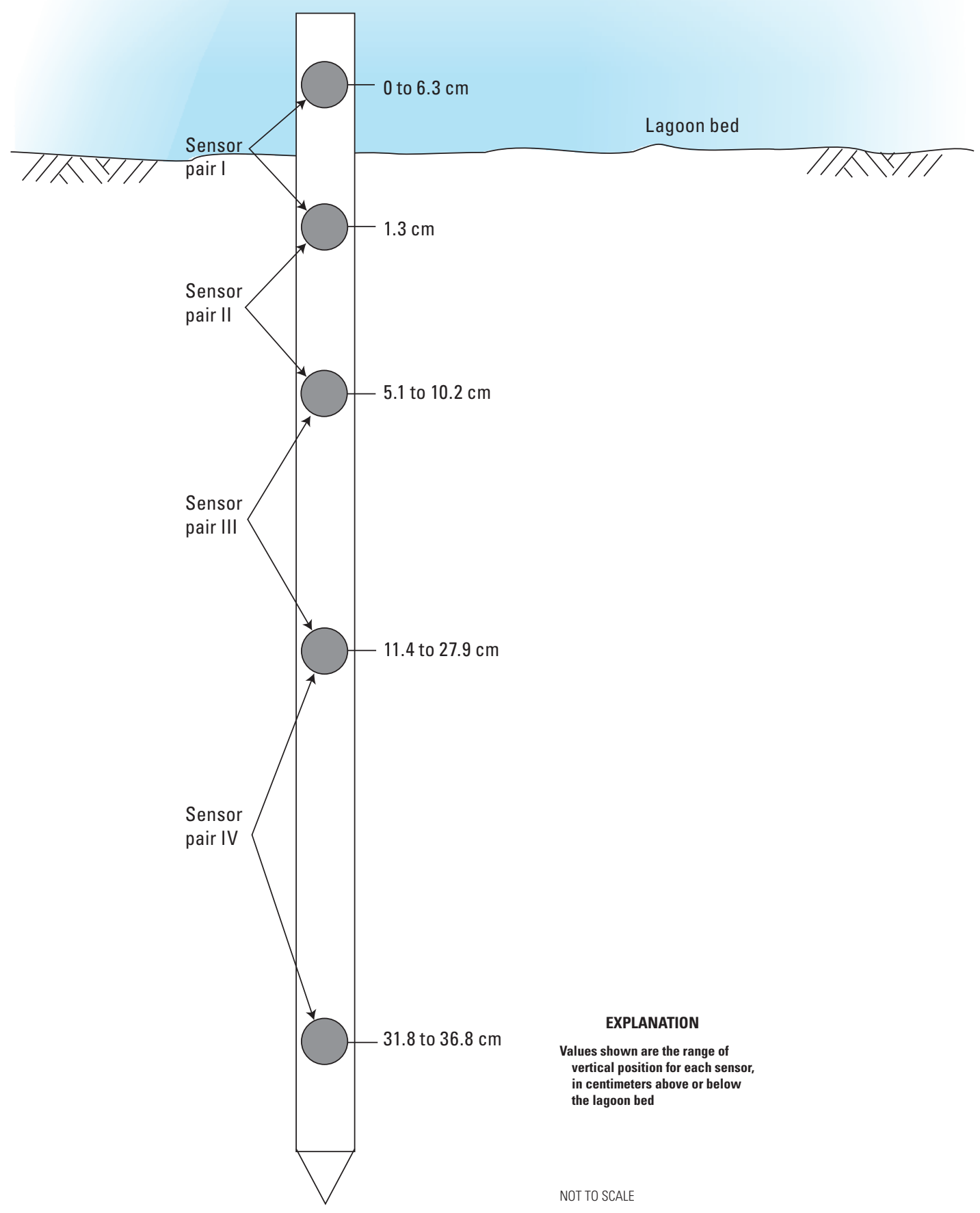

Figure 2. Vertical profile of a temperature sensor used in this study. 


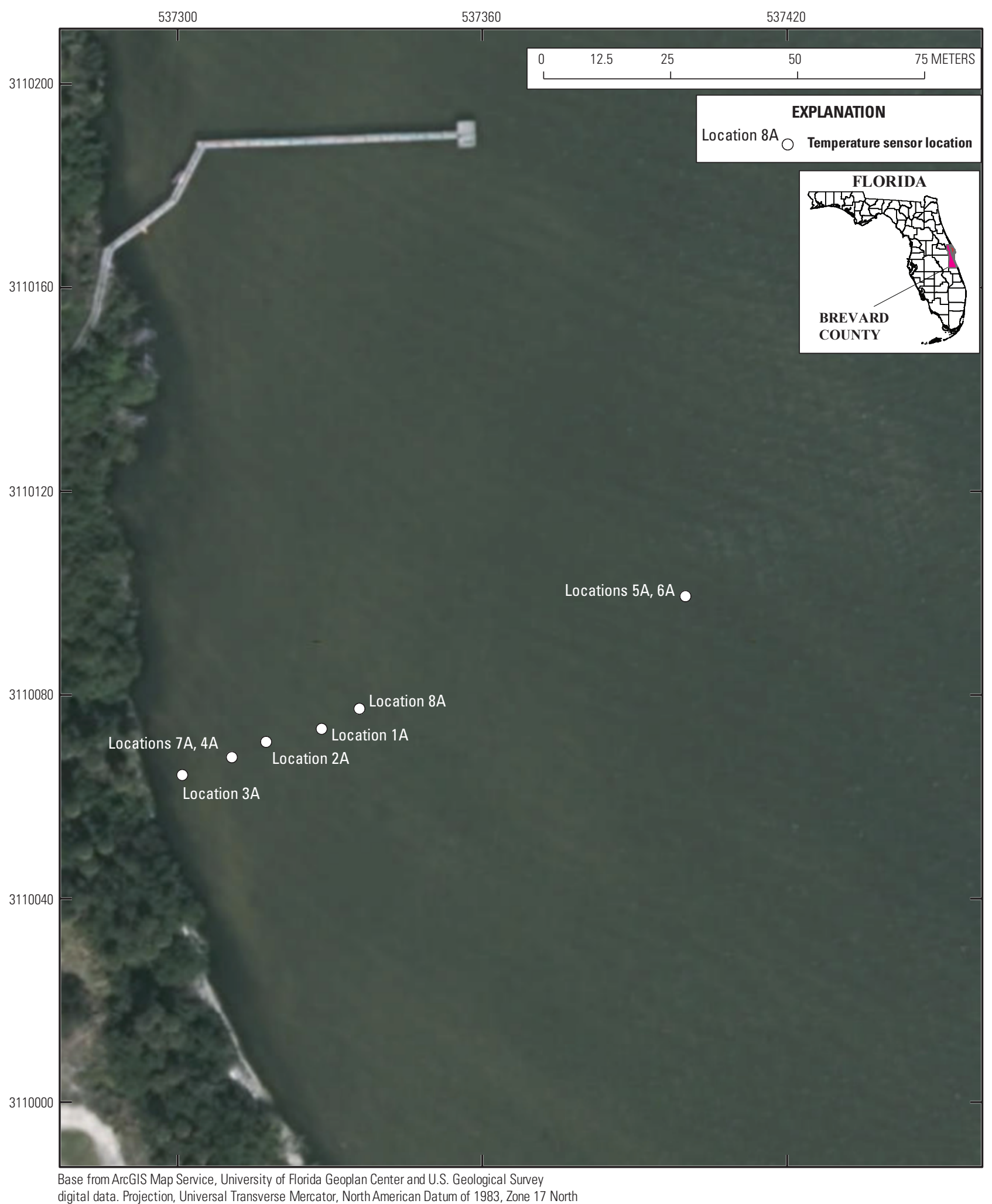

Figure 3. Temperature sensor locations at the Eau Gallie study area during March 23-April 28, 2017. 


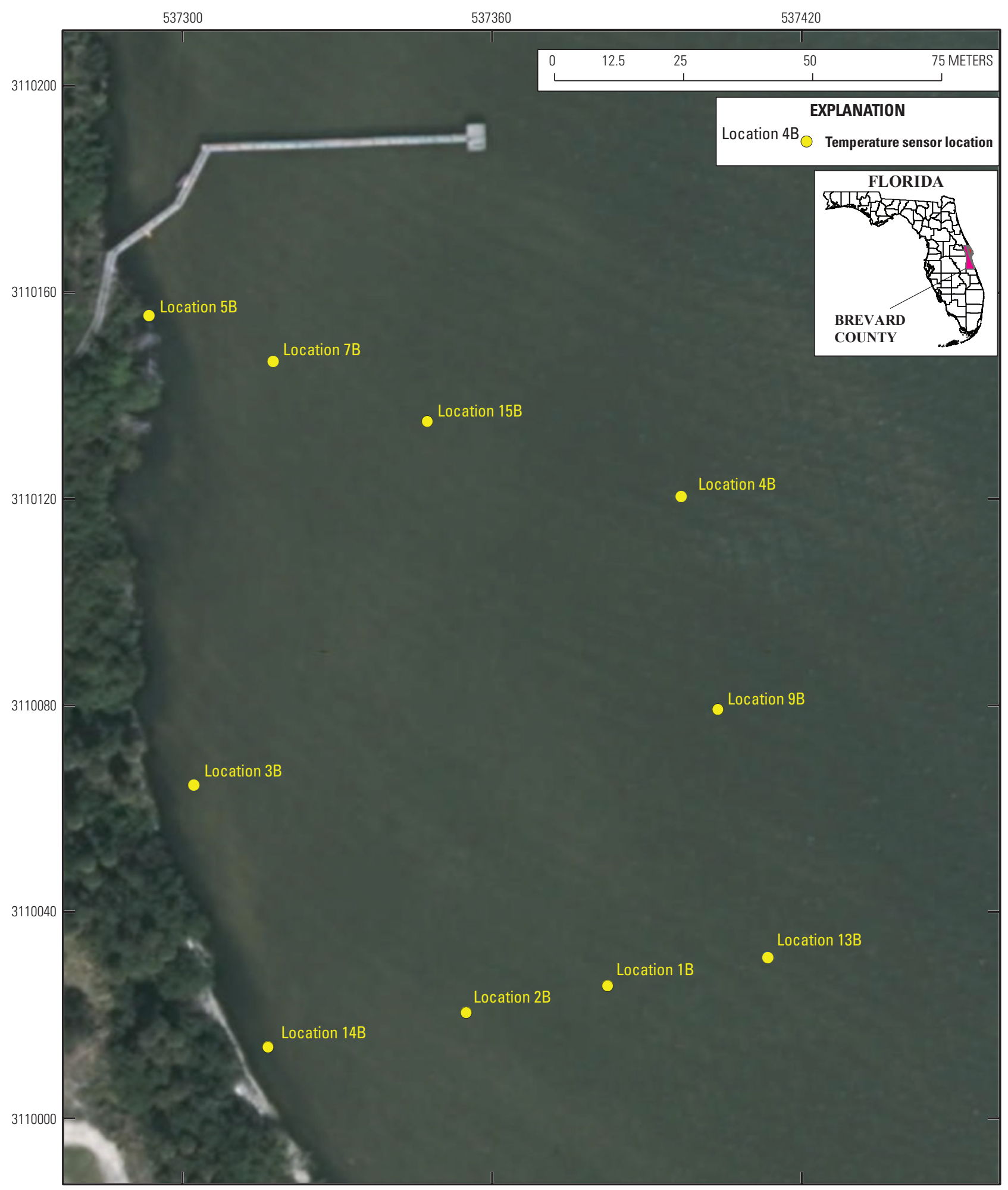

Base from ArcGIS Map Service, University of Florida Geoplan Center and U.S. Geological Survey

digital data. Projection, Universal Transverse Mercator, North American Datum of 1983, Zone 17 North

Figure 4. Temperature sensor locations at the Eau Gallie study area during June 1-November 3, 2017. 


\section{Computation of Groundwater Seepage}

The estimation of groundwater seepage flux from temperature data involves determining the vertical fluid flux $q$ (Darcy flux) of the one-dimensional heat transport equation:

$$
\frac{\partial T}{\partial t}=k_{e} \frac{\partial^{2} T}{\partial z^{2}}-q \frac{C_{w}}{\bar{C}} \frac{\partial T}{\partial z},
$$

where

$$
\begin{aligned}
T= & \text { temperature, } \\
t= & \text { time, } \\
k_{e}= & \text { the thermal diffusivity of the saturated } \\
& \text { sediments, } \\
z \quad= & \text { length along the flow path }, \\
q \quad= & \text { vertical fluid flux, } \\
C_{w}= & \text { water volumetric heat capacity, and } \\
\bar{C}= & \text { the saturated sediment volumetric heat } \\
& \text { capacity. }
\end{aligned}
$$

As heat is transported through both grains and water-filled pores, the typical controlling flow parameter of hydraulic conductivity is not explicitly contained in the heat transport equation. Given the values of the constants and the spatial and temporal variations in temperature, the fluid flux, $q$, can be computed. However, $k_{e}$ and $\bar{C}$ can have substantial uncertainty, and both are related to the total sediment porosity, $n$, by

$$
k_{e}=\frac{\lambda}{\bar{C}}+\beta \frac{q}{n},
$$

and

$$
\bar{C}=\frac{n C_{w}+(1-n) C_{s}}{C_{w}+C_{s}},
$$

where

$$
\begin{aligned}
\lambda & =\text { saturated thermal conductivity, } \\
\beta & =\text { thermal dispersivity (the term is typically } \\
& \text { negligible over }<1 \text {-m lengths), and } \\
C_{s} & =\text { sediment-grain volumetric heat capacity. }
\end{aligned}
$$

Given a time series of temperature in a vertical profile and estimates of $n, \lambda, \beta, C_{w}$, and $C_{s}$, the vertical flux, $q$, can be estimated by discretizing equation 1 in time and space. Various methods have been developed to fit the fluid flux to temperature data, and two different modeling techniques were applied to the temperature data from the Eau Gallie study area to determine seepage flux rates. These two simulators are 1DTempPro (Koch and others, 2016) and VFLUX (Gordon and others, 2012). The methodology and applications of each model are described below. The simulation input and output files discussed herein are available in Swain (2018). Simulations require several executables, MATLAB Version 2014a or later, and several MATLAB toolboxes as described in Swain (2018).

\section{Application of 1DTempPro Model}

The 1DTempPro program uses the groundwater flow and transport code VS2DH in a graphical user interface to calibrate groundwater flux to measured temperature time series (Koch and others, 2016). Originally designed for computation of flux from defined heat parameters and temperature profiles, Version 2 of 1DTempPro has a parameter optimization method wherein one of the parameters, $q, n, \lambda, \beta$, or $C_{s}$, can be estimated individually via an inverse-modeling approach. Given the degrees of freedom (number of unknowns), reasonable estimates of the parameters are needed from independent sources, and an estimate of $q$ at some simulation time is used to test known values of the other input parameters.

By applying 1DTempPro to some of the temperature data collected at the Eau Gallie study area, simulation results were used to assist in the development of the VFLUX simulation and to compare with the VFLUX simulation results. Location 1A data for the March-April period (fig. 3; Prinos and Briggs, 2017) were used to test the $n, \lambda, \beta$, and $C_{\text {s }}$ values for suitability. For a given set of parameters chosen, an average $q$ value for each day was computed from the 24 hourly temperature profiles (fig. 5). This simulation period was sufficiently dry to assume the seepage flux, $q$, was near zero, so using suitable $n, \lambda, \beta$, and $C_{s}$ values in the 1DTempPro parameter-estimation solution was expected to produce minimal $q$ values. Each daily flux was computed separately, because a time-series simulation cannot be specified to solve for a variable flux in 1DTempPro. When evaluating results, it must be considered that different combinations of the controlling parameters could result in near-zero computed $q$. Through manual adjustment of parameters and a preference for standard parameter values that might be expected for the fine sand soil type at Eau Gallie (Scott, 1993), the following values were accepted:

- Porosity $n=0.28$

- Thermal conductivity $\lambda=1.885$ watts per meter-degrees Celsius $\left(\mathrm{W} /\left[\mathrm{m}^{\circ} \mathrm{C}\right]\right)$

- Thermal dispersivity $\beta=0.001 \mathrm{~m}$

- Sediment heat capacity $C_{s}=2.1 \times 10^{6}$ joules per meter-degrees Celsius $\left(\mathrm{J} /\left[\mathrm{m}^{3}{ }^{\circ} \mathrm{C}\right]\right)$

\section{Application of VFLUX Model}

The VFLUX program also estimates one-dimensional vertical fluid flow in saturated porous media. The program has several different analytical solution methods that are based on isolating the fundamental signal in the temperature data (usually the diurnal cycle) using a Dynamic Harmonic Regression method and utilizing the resulting amplitude and phase differences between sensor depths in analytic formulations to determine vertical water flux 


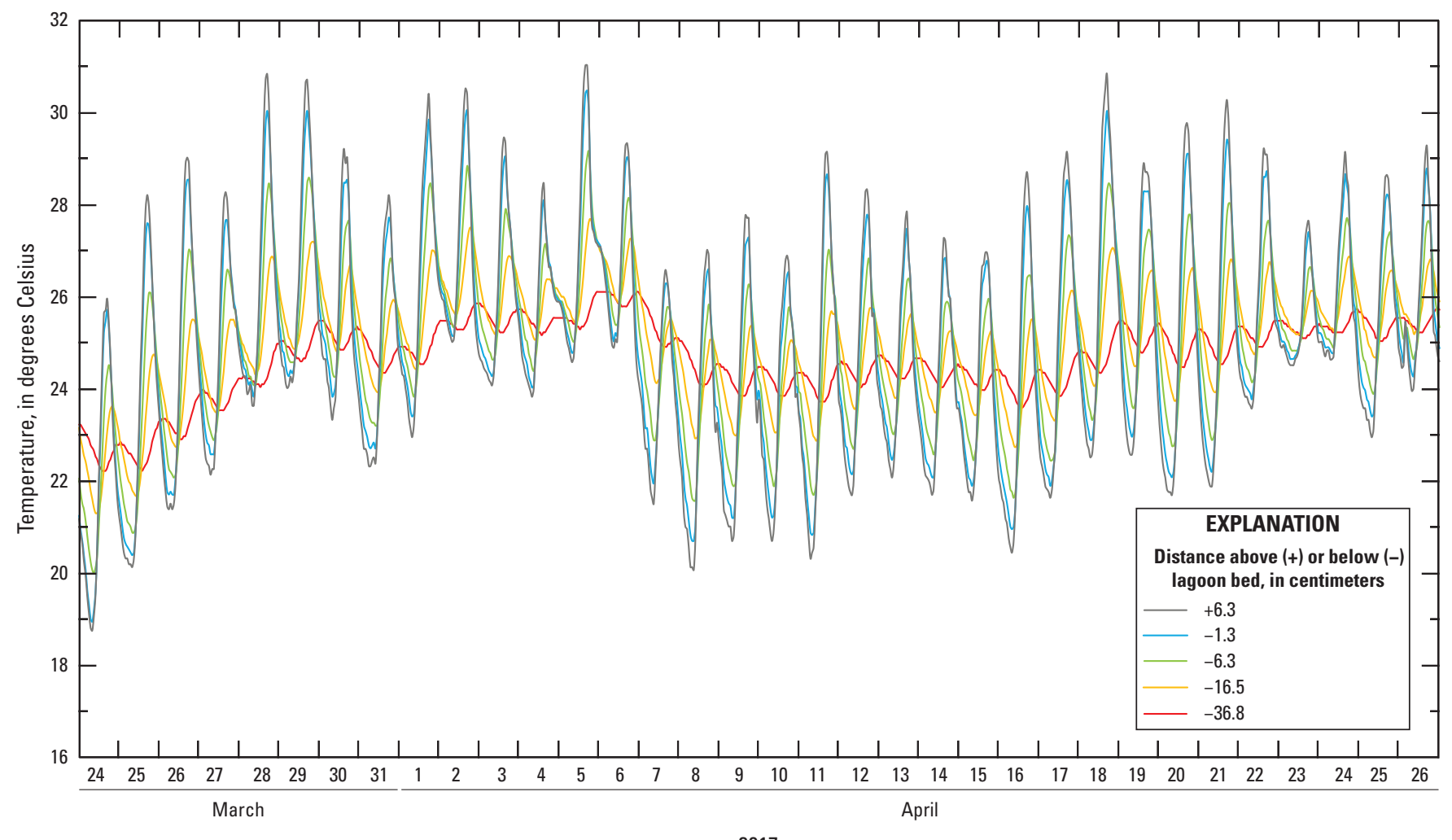

2017

Figure 5. Measured temperatures at various depths for location 1A in the Eau Gallie study area (location shown in fig. 3).

(Gordon and others, 2012). The analytic formulations include those by Hatch and others (2006); Keery and others (2007); McCallum and others (2012); and Luce and others (2013). All these formulations use the ratio of amplitudes and (or) the time lag between two temperature signals to determine the vertical flux from the advective-transport characteristics.

For a seepage-flux scenario that predominantly involves upwelling from groundwater to surface water, as is assumed at the IRL, the solution methods that use amplitude attenuation with depth, rather than phase differences, are considered more applicable (Briggs and others, 2014). The phase signal at greater depths tends to dissipate rapidly when the advective flux is upwards, whereas the amplitude signal does not dissipate as much for these conditions. The Hatch formulation uses the amplitude method and is considered more appropriate for this study.

VFLUX solves for vertical flux on the basis of the time series of temperature differences between each possible pair of sensors in a vertical column (fig. 2). The derived seepage flux values inevitably differ, and the user must decide which is most representative of the seepage exchange between groundwater and surface water. Whereas 1DTempPro estimates a vertically averaged flux, the VFLUX-estimated flux varies with depth, and values determined from sensors nearest to the surface should be the closest values corresponding to seepage exchange with the lagoon as well as where flux should be closest to vertical. In this analysis, the location of the topmost sensor at each location varies between $1.3 \mathrm{~cm}$ below the surface to $5.1 \mathrm{~cm}$ above the surface, and the calculated flux varies substantially on the basis of which sensor pairs are used for computation. In order to determine the most representative pair or combination of pairs of sensors, a comparison is made between simulated flux values using VFLUX and flux values using 1DTempPro.

Not every temperature measurement location in the Eau Gallie study area has a sensor above the lagoon bed. For example, in the March-April data, only 4 locations out of 8 have a sensor in the surface water. To account for missing sensors above the lagoon bed at locations $3 \mathrm{~A}, 4 \mathrm{~A}, 5 \mathrm{~A}$, and $8 \mathrm{~A}$ (fig. 3), a linear relationship was developed between the fluxes computed at sensor pair below the lagoon bed and sensor pairs including the surface-water sensor (fig. 2). This linear relationship was then applied at all locations that do not have a surface-water sensor to estimate flux at what would be the uppermost pair of sensors.

Values of $n, \lambda, \beta, C_{w}$, and $C_{s}$ must be input by the user to VFLUX. The tested and accepted values in the 1DTempPro simulation listed in the preceding section, although not proven to be unique, are considered appropriate for the VFLUX simulation. This allows a direct comparison of the two simulation methods and aids evaluation of the differences in model results.

A distinct temperature signal is necessary to obtain the proper solution of the VFLUX formulations. The temperature signal can be difficult to define when temperature differences along the vertical profile are small. Additionally, VFLUX 
solves separately for individual pairs of sensors in the vertical column, whereas 1DTempPro solves the heat transport equation for the entire vertical column of sensors. However, VFLUX can solve for a variable seepage flux over an extended time series, contrasting with 1DTempPro, which represents a constant seepage flux for each simulation period. Thus, for this study, VFLUX was used to estimate the longer flux time series on the basis of characteristic temperature signals, and 1DTempPro was applied to more limited time series to confirm VFLUX results and help determine the most representative sensor pairs in the VFLUX solution.

\section{Estimation of Groundwater Seepage Exchange With Lagoon Surface Water}

The 1DTempPro and VFLUX simulations were applied to vertical heat-profile measurements at multiple locations offshore in the Eau Gallie study area (figs. 1, 3, and 4) for two time periods as specified above. The March-April period was relatively dry and was assumed to have seepage flux rates of very low magnitude. The June-November period contained major hydrologic events, including Hurricane Irma on September 10, 2017, and was assumed to have periods of substantial groundwater seepage flux into the lagoon.

\section{Dry Season Simulation Period}

The results of the March-April 1DTempPro simulation indicate the seepage flux at this location varied in direction over time with absolute values under 10 centimeters per day (cm/d; fig. 6). VFLUX simulates the same time period at location $1 \mathrm{~A}$ with a 2-hour time step (twice the sampling rate). A comparison of different combinations of sensor pair computed values in VFLUX with the 1DTempPro results indicated the closest match occurred with the average of the highest three sensor pairs (pair I, II, and III in fig. 2). The lowest sensors deviated the most from the 1dTempPro values and showed a negative bias. The temperature signal is weakest at the lowest sensors because of much smaller temperature fluctuations. For the March-April 2017 period, the average temperature fluctuation amplitudes of each sensor from the top downward were $2.8,2.4,1.7,1.0$, and $0.3{ }^{\circ} \mathrm{C}$. With such a small amplitude at the lowest sensor, the 4th sensor pair is quite unreliable and uncertainty in the temperature signal can create inaccuracies and bias in the computed seepage flux. This average of the top three sensor pairs was chosen for subsequent analyses at other locations.

Magnitudes of bidirectional seepage and patterns of variation are similar, as indicated by comparison of the 1DTempPro and VFLUX results (fig. 6). More fluctuations are visible in the VFLUX simulation than in the daily 1DTempPro

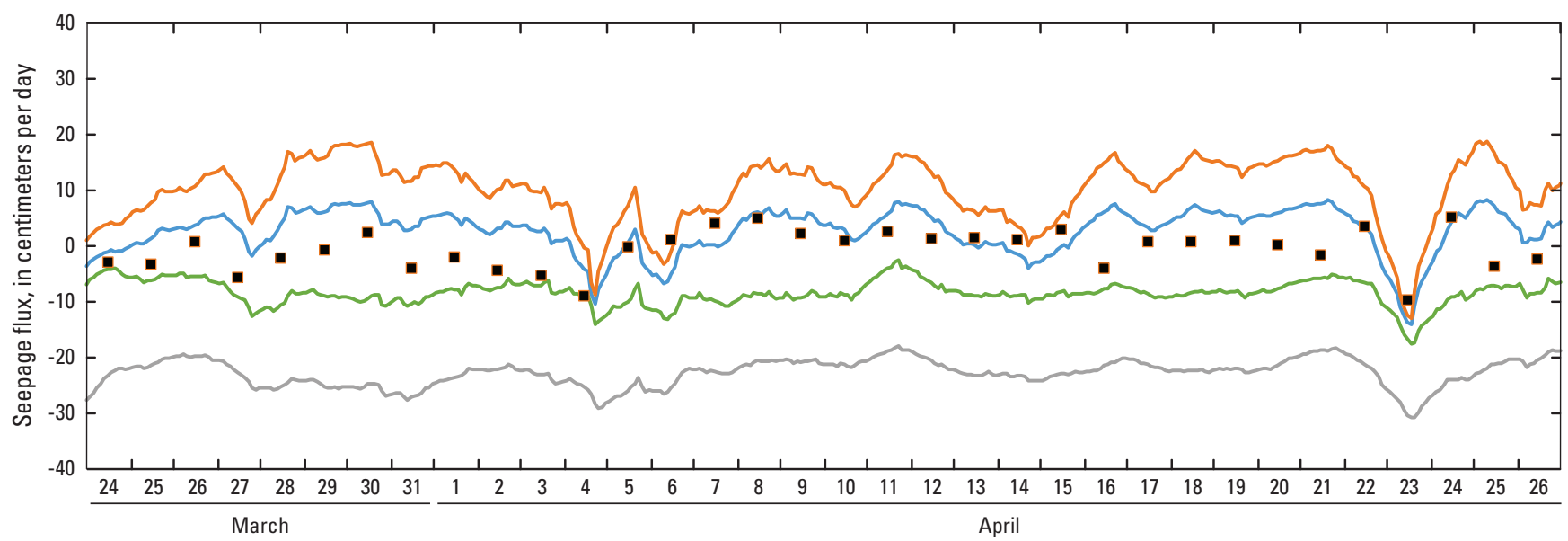

2017

EXPLANATION

VFLUX simulated values for

Average 1st and 2nd sensor pairs

Average 2nd and 3rd sensor pairs

Average 3rd and 4th sensor pairs

Average top 3 sensor pairs

- 1DTempPro simulated values

Figure 6. 1DTempPro and VFLUX results at location 1A in the Eau Gallie study area, March-April 2017. 
results, partially because of the higher temporal resolution of the VFLUX simulation. The 1DTempPro simulation calculates a constant seepage flux over each day on the basis of the hourly measured temperature distributions, whereas VFLUX calculates a flux every 2 hours based on the hourly data. Differences in solution methods also were a factor, because 1DTempPro solves for seepage flux using the heattransport equation, whereas VFLUX delineates temperature fluctuation signals and analytically tracks their advective movement.

\section{Estimating Flux for Locations Lacking A Surface-Water Sensor}

For simulating the March-April period using VFLUX, the offshore locations 3A, 4A, 5A, and 8A do not have a sensor in the surface water above the lagoon bed, so sensor pair I is missing (fig. 2). A linear fit was assumed in order to develop equations relating the flux computed from the sensor pair below the lagoon bed (pair II in fig. 2) and the average fluxes
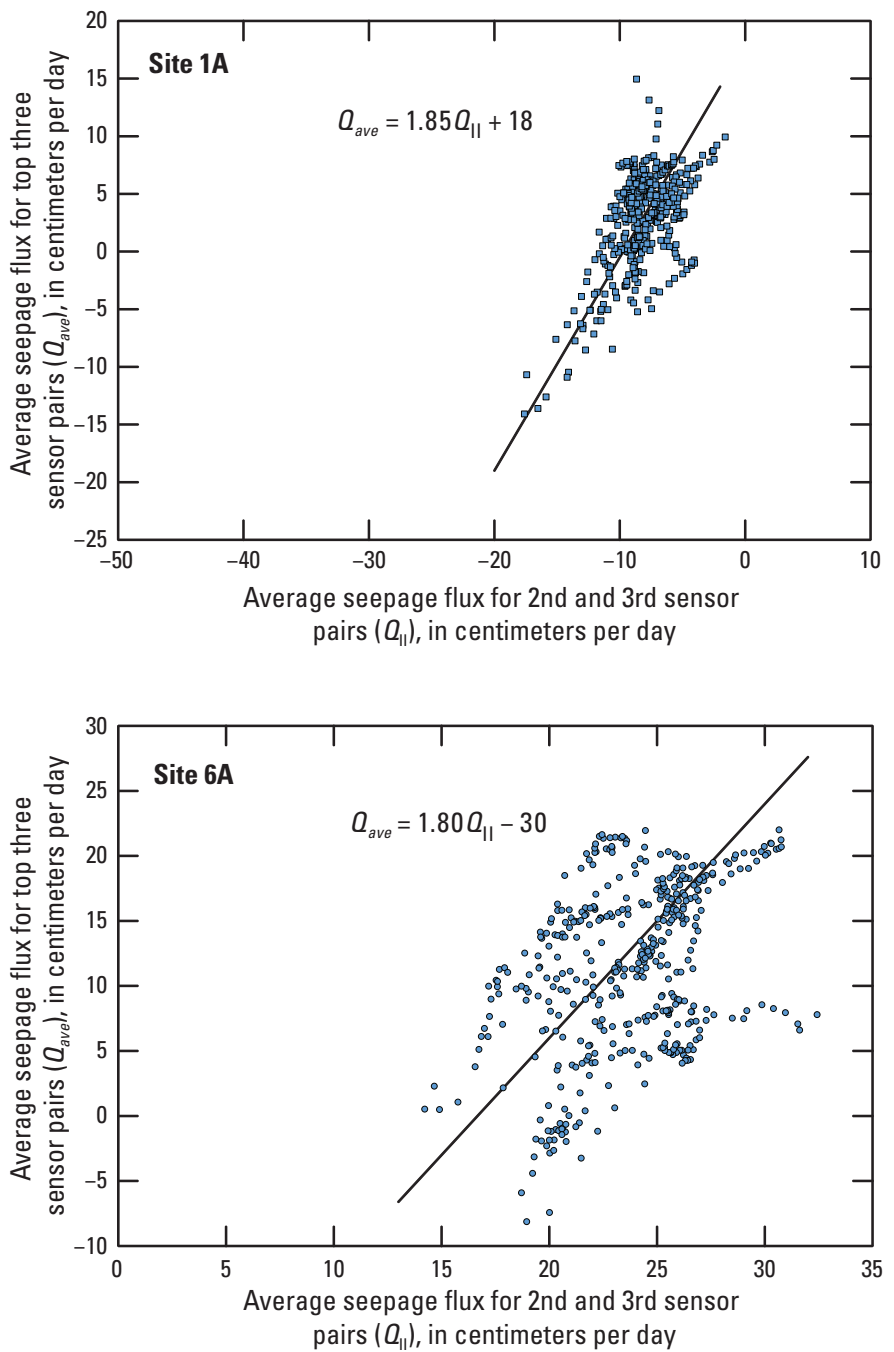

for the top three sensor pairs (pairs I, II, and III, fig. 2) for locations $1 \mathrm{~A}, 2 \mathrm{~A}, 6 \mathrm{~A}$, and $7 \mathrm{~A}$ using

$$
Q_{a v e}=A Q_{\mathrm{II}}+B \text {, }
$$

where

$Q_{\text {ave }} \quad$ is the average flux for the top three sensor pairs I, II, and III;

$Q_{\mathrm{II}} \quad$ is the flux for the sensor pair II below the lagoon bed; and

$A$ and $B \quad$ are the slope and intercept coefficients, respectively.

Given the apparent scatter in the data, the best-fit parameters were manually chosen to visually match most of the data, as shown in figure 7 . These parameters vary between locations, with location 6A differing from the others in that it is the only one having a negative intercept coefficient, $B$ (table 1 ). Location $6 \mathrm{~A}$ is also much farther offshore than the other three locations, which may be a factor. A decision was made to use average parameters from the three locations having a sensor
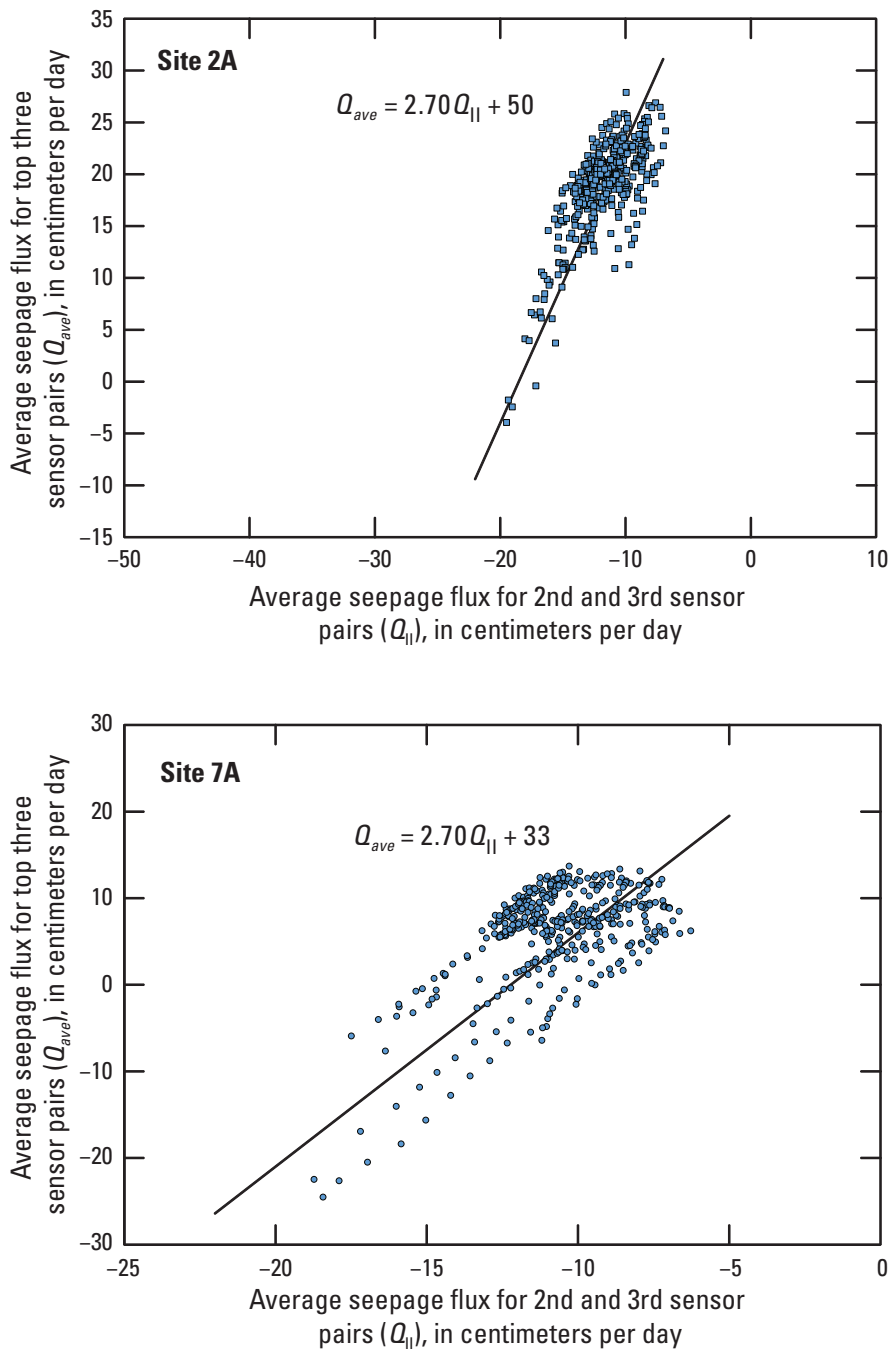

Figure 7. Average flux values from the highest three sensor pairs and flux values from the highest sensor pair beneath the lagoon bed in the Eau Gallie study area, March-April 2017. 
Table 1. Derived coefficients for linear fit equation $\left(Q_{a v e}=A Q_{\|}+B\right)$ for March 24-April 28, 2017, temperature data.

$\left[Q_{\text {ave }}\right.$ is average of fluxes computed with top three sensor pairs; $Q_{\mathrm{II}}$ is flux computed with second sensor pair from the top; $A$ and $B$ are linear fit coefficients]

\begin{tabular}{lcc}
\hline \multicolumn{1}{c}{ Location } & $\boldsymbol{A}$ & $\begin{array}{c}\boldsymbol{B} \\
\text { (cm/d) }\end{array}$ \\
\hline $1 \mathrm{~A}$ & 1.85 & 18 \\
$2 \mathrm{~A}$ & 2.70 & 50 \\
$6 \mathrm{~A}$ & 1.80 & -30 \\
$7 \mathrm{~A}$ & 2.70 & 33 \\
Applied to locations & 2.40 & 34 \\
3A, 4A, 5A, and 8A & & \\
\hline
\end{tabular}

above the bed, except at location $6 \mathrm{~A}$, to compute fluxes for the locations without a sensor above the bed (locations $3 \mathrm{~A}$, $4 \mathrm{~A}, 5 \mathrm{~A}$, and $8 \mathrm{~A}$, table 1). Thus, the equivalent fluxes for the average of the top three sensor pairs (approximated as if there were a sensor above the bed) were calculated using $Q_{\text {ave }}=2.4 Q_{\text {II }}+34(\mathrm{~cm} / \mathrm{d})$.

\section{Simulations at all Locations}

The March-April time series of seepage fluxes simulated with VFLUX were similar in magnitude and pattern among the eight different offshore locations (fig. 8). Temporal fluctuations in seepage flux were distinct close to shore (location 3A located $4 \mathrm{~m}$ offshore), whereas those farthest offshore tended to fluctuate less (locations 5A and 6A both $110 \mathrm{~m}$ offshore). It would be expected that seepage responses to environmental variations are dampened further offshore, away from nearshore effects. The average seepage flux over the March 24-April 20, 2017, period had a maximum of nearly $20 \mathrm{~cm} / \mathrm{d}$ upward and varied substantially within $40 \mathrm{~m}$ of shore (fig. 9). The two farthest locations $110 \mathrm{~m}$ offshore had similar average upward seepage flux values of about $10 \mathrm{~cm} / \mathrm{d}$ and probably indicate a decline in seepage flux between 40 and $110 \mathrm{~m}$ offshore. The large spatial variability in the locations and the limited number of locations, however, precludes definitive conclusions other than that upward seepage flux exists more than $100 \mathrm{~m}$ offshore and tends to be less than $20 \mathrm{~cm} / \mathrm{d}$ nearshore.

\section{Wet Season Simulation Period}

The June-November period contains wetter hydrologic events, including Hurricane Irma, than the March-April period. Simulation results obtained from VFLUX were less conclusive for this wetter period in discerning the fundamental signal in the temperature data at a number of locations, most likely because the advection of the higher seepage flux rate obscured the diurnal temperature variations. VFLUX was unable to delineate the fundamental signal for any substantial period of time in the simulation for locations $2 \mathrm{~B}, 4 \mathrm{~B}, 5 \mathrm{~B}$, and 15B (fig. 4). Successful simulations, each containing solutions for large portions of the time series, were made at locations 1B, 3B, 7B, 9B, 13B, and 14B, providing sufficient insight into spatial seepage variability.

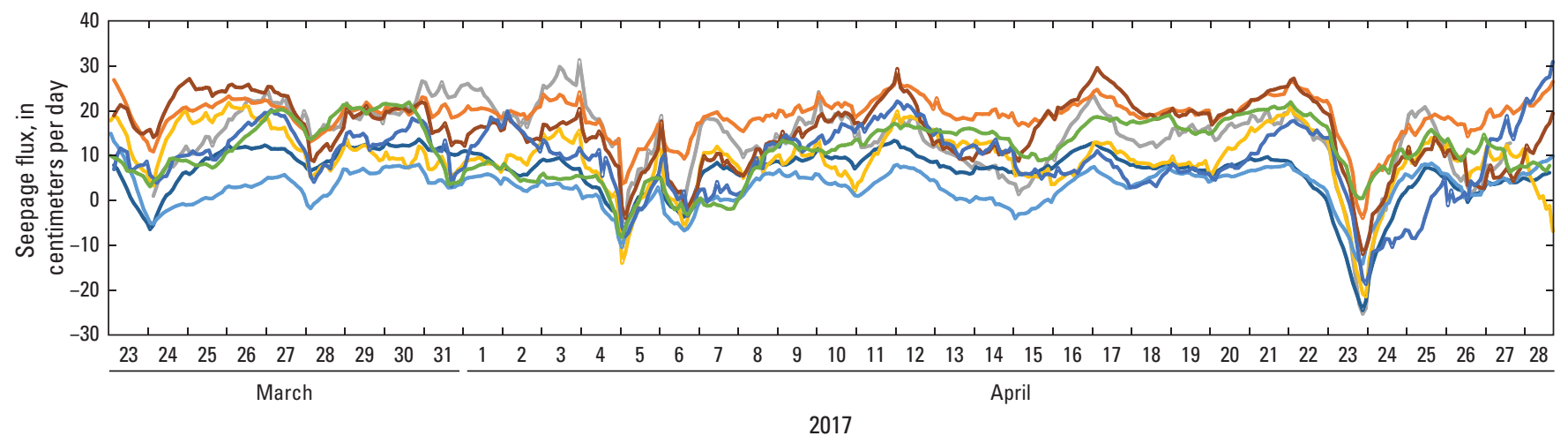

2017

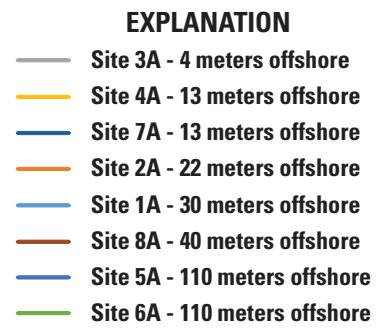

Figure 8. Computed seepage flux in the Eau Gallie study area, March-April 2017. 


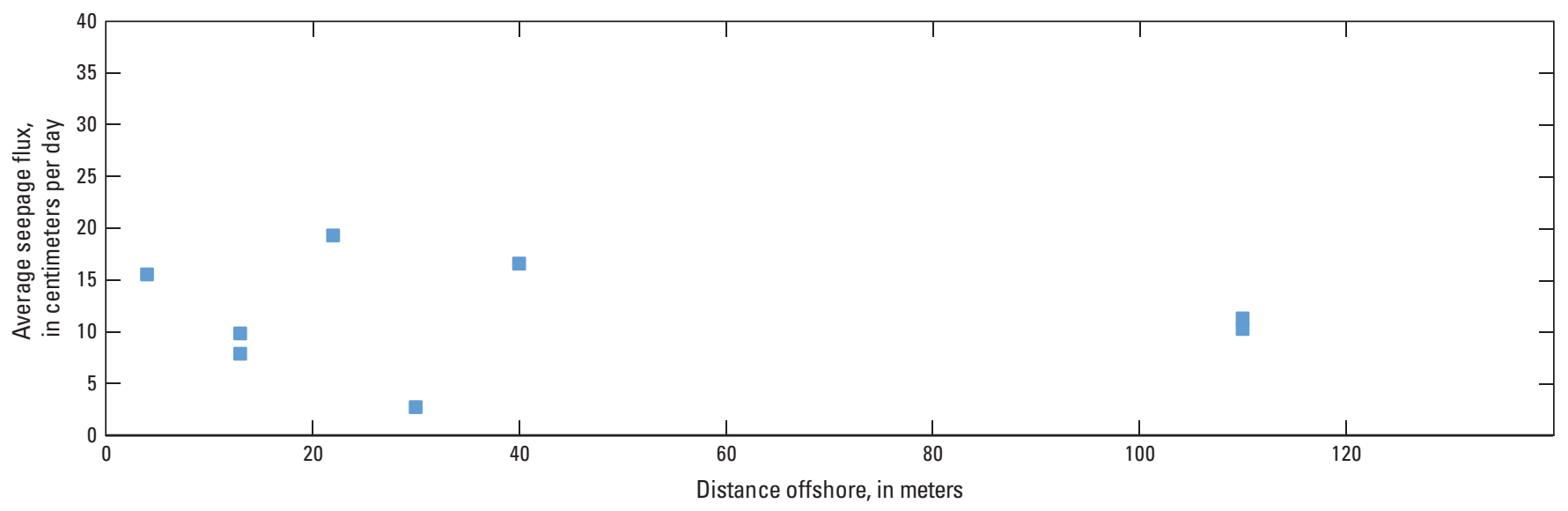

Figure 9. Average seepage flux and distance offshore in the Eau Gallie study area, March 24-April 20, 2017.

As was done for the March-April data, those locations having a surface-water sensor above the lagoon bed (locations 1B, 9B and 13B) are used to develop the linear estimator for those locations without a surface-water sensor (locations 3B, 7B, and 14B). The relationship between average flux for the sensor pairs I, II, and III, and the average flux for the sensor pairs II and III for each location is different before and after the landfall of Hurricane Irma on September 10, 2017 (fig. 10). This change is most likely due to disturbance of the lagoon bed changing the sensor-placement depths; it was not possible to verify the sensor depths when removing them. The change also indicates that computations of seepage flux rates after the hurricane may be substantially compromised if the sensor depths change from assumed values. Linear fit coefficients were developed for each location for the periods before and after Hurricane Irma (table 2). These coefficient values indicate that conditions changed substantially at locations $1 \mathrm{~B}$ and $9 \mathrm{~B}$, but much less so at location 13B (fig. 10). The changes manifested by the hurricane primarily affect the linear equation slope $A$. It is possible that the highest sensor in the surface water became partially buried by sediment during the hurricane surge, and so its measured temperature time series became similar to the other subsurface sensors. The prehurricane coefficients are similar between locations and coefficients were chosen to estimate fluxes at the locations without a surface-water sensor (locations 3B, 7B, and 14B) using $Q_{\text {ave }}=0.8 Q_{\mathrm{II}}+30(\mathrm{~cm} / \mathrm{d})$.

Successful VFLUX simulations were achieved for the period between June 19 and October 27, 2017, and were more continuous and reliable before Hurricane Irma made landfall September 10; substantial periods of failed numerical solutions occurred at most of the locations post-landfall (fig. 11), most likely for the reasons discussed previously. Most of the locations shown have a continuous simulation before the hurricane except for location 7B where numerical solutions failed during large downward seepage fluxes, such as on July 30 and August 12 (fig. 11). Only at location 14B was a continuous simulation maintained after the hurricane.

The June-November simulations show higher seepage flux rates than the March-April simulations, sometimes as great as $40 \mathrm{~cm} / \mathrm{d}$, and greater than $60 \mathrm{~cm} / \mathrm{d}$ at location $3 \mathrm{~B}$ nearest the shore, with a large downward flux simulated during the hurricane followed by a reverse upward seepage flux as rainfall increased groundwater inflows (fig. 11). Location 3B is only $5 \mathrm{~m}$ from the shore (fig. 4) and had the largest upward seepage flux during the rainfall response period, and location 7B, somewhat farther from shore, had the second largest upflow. The rest of the locations further offshore showed a greater downward seepage flux during the hurricane and less upward rebound. The effects of the hurricane including the storm surge, appeared to have initially raised lagoon levels, reversing the surface-water to groundwater gradient and driving the seepage flux downward. Then as the inland precipitation recharge raised the groundwater levels, the seepage flux was driven upwards from the groundwater to the lagoon. The storm-surge effects appear to be dominant at most of the locations farther offshore, but one of the two locations $5 \mathrm{~m}$ from shore shows a dominant upwelling effect.

Most of the locations show similar magnitudes of temporal fluctuations, except for location $3 \mathrm{~B}$, which shows much smaller temporal fluctuations (fig. 11). Location 14B is a about the same distance from shore as location $3 \mathrm{~B}$ but shows larger fluctuations similar to those at sites farther offshore (fig. 11). Location 3B also shows the largest upward seepage flux during and after the hurricane, as discussed earlier, so the connectivity to groundwater and the lagoon may be substantially different at location 3B than at other sites.

Given the difficulty in simulating parts of the June-November period using the VFLUX method, a subperiod was chosen during which continuous simulations were computed at all locations for examining average seepage flux rates (June 20-July 20). The highest seepage flux rates were at one of the locations $5 \mathrm{~m}$ offshore, about $27 \mathrm{~cm} / \mathrm{d}$, and the rates appear to decrease with distance offshore out to $70 \mathrm{~m}$ (fig. 12). The seepage fluxes at 110 and $130 \mathrm{~m}$ offshore were over $20 \mathrm{~cm} / \mathrm{d}$, only slightly lower than the highest nearshore value and about twice as high as values at this distance offshore in the March-April simulations (fig. 9). The simulations indicate that, relative to the March-April period, the June-July period exhibited greater variability in seepage rates and direction, with higher mean upward seepage flux extending farther offshore. 

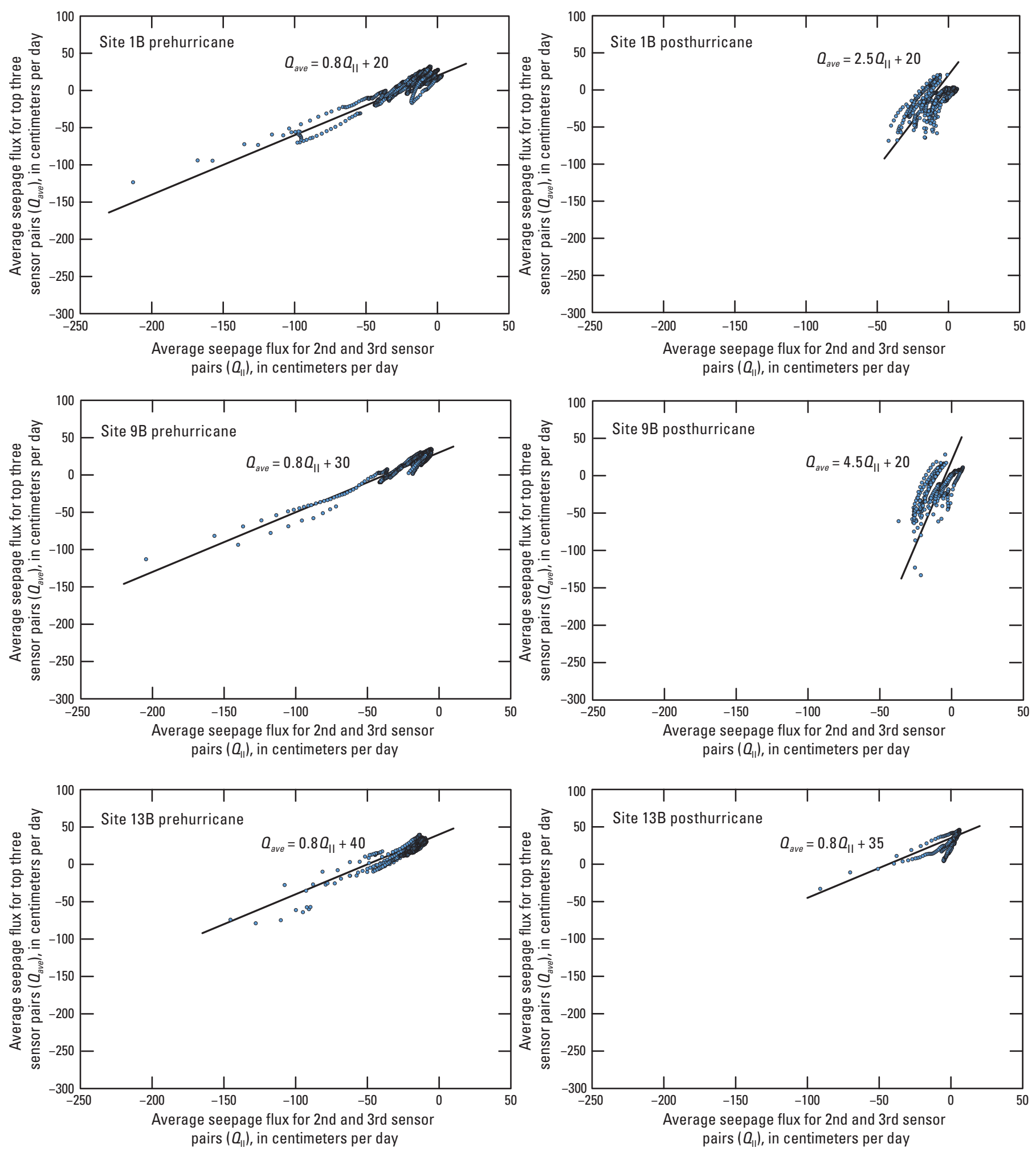

Figure 10. Flux computed from top three sensor pairs and highest sensor pair beneath the lagoon bed in the Eau Gallie study area for June 1-September 9, 2017, and September 11-November 3, 2017. 
Table 2. Derived coefficients for linear fit equation $\left(Q_{a v e}=A Q_{11}+B\right)$ for June 1-November 3, 2017, temperature data.

[Dates shown as month, day, year. $Q_{\text {ave }}$ is average of fluxes computed with top three sensor pairs; $Q_{\text {II }}$ is flux computed with second sensor pair from the top; $A$ and $B$ are linear fit coefficients]

\begin{tabular}{|c|c|c|c|c|}
\hline \multirow[b]{2}{*}{ Location } & \multicolumn{2}{|c|}{ 5/21/2017-9/9/2017 } & \multicolumn{2}{|c|}{ 9/11/2017-11/7/2017 } \\
\hline & $\boldsymbol{A}$ & $\begin{array}{c}B \\
(\mathrm{~cm} / \mathrm{d})\end{array}$ & $\boldsymbol{A}$ & $\begin{array}{c}B \\
(\mathrm{~cm} / \mathrm{d})\end{array}$ \\
\hline 1B & 0.8 & 20 & 2.5 & 20 \\
\hline 9B & 0.8 & 30 & 4.5 & 20 \\
\hline 13B & 0.8 & 40 & 0.8 & 35 \\
\hline Applied to locations $3 \mathrm{~B}, 7 \mathrm{~B}$, and $14 \mathrm{~B}$ & 0.8 & 30 & -- & -- \\
\hline
\end{tabular}

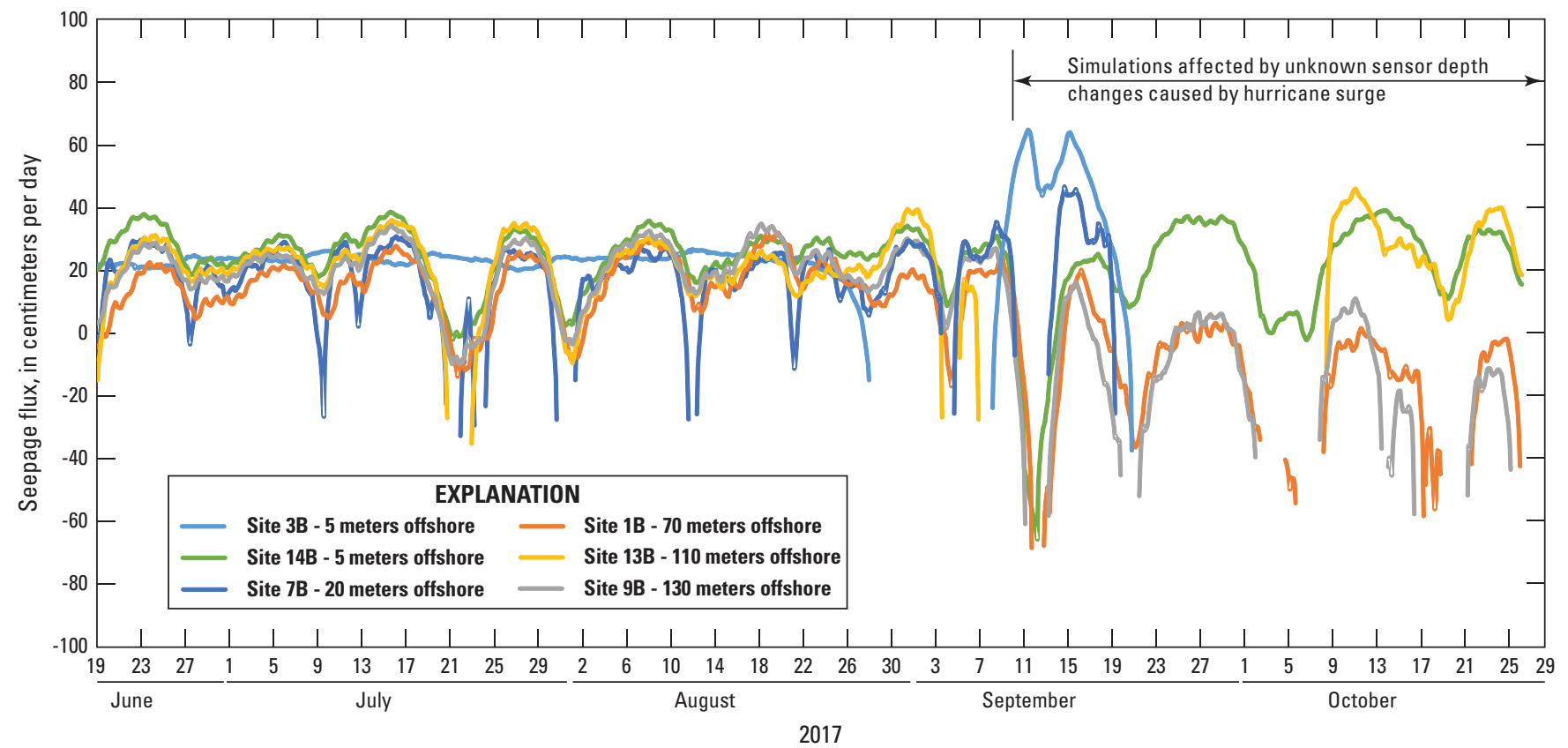

Figure 11. Computed seepage flux in the Eau Gallie study area, June-October 2017.

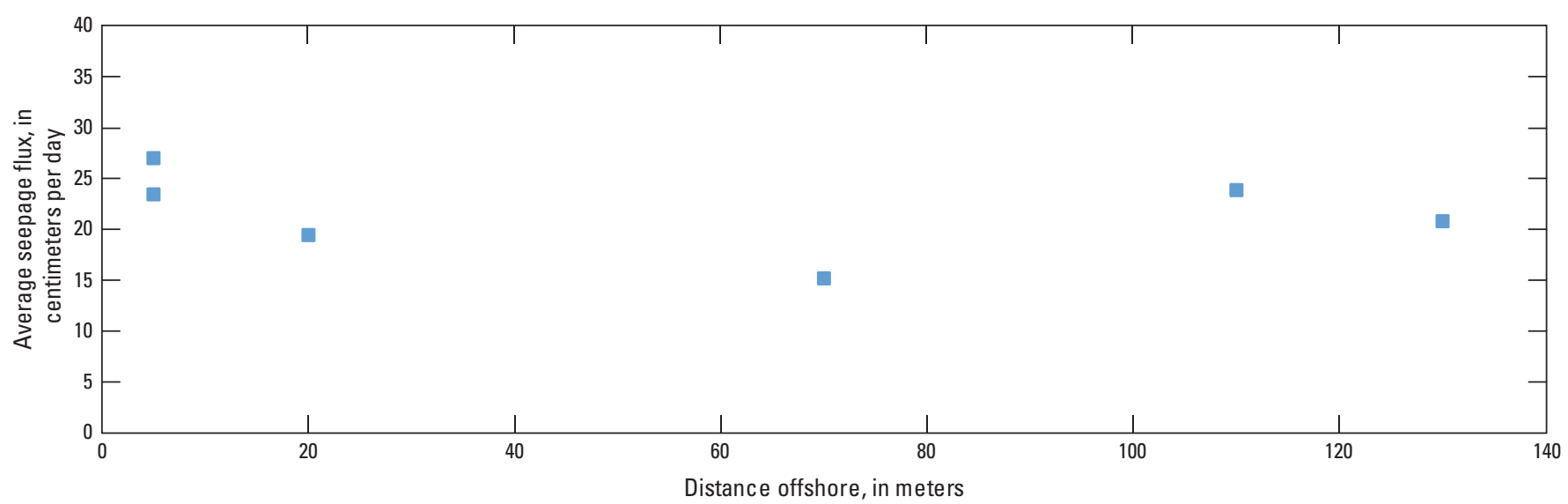

Figure 12. Relation between average seepage flux and distance offshore in the Eau Gallie study area, June 20-July 20, 2017. 


\section{Limitations}

The results described in this report have limitations based on the data collected, the assumptions made, and the computational methods used. A complete determination of water and nutrient fluxes into the IRL is beyond the scope of this report. When interpreting these simulation results, the following limitations must be considered:

1. The seepage flux at discrete locations is estimated, which does not describe the total groundwater contributions nor quantify the groundwater transport of nutrients to the IRL.

2. The computational techniques are both indirect methods that estimate seepage flux on the basis of the behavior of the vertical temperature profile. The 1DTempPro simulation iteratively determines a seepage flux that results in a temperature profile fitting measured values. The VFLUX simulation delineates the frequency of the temperature signal and uses the ratio of amplitudes between two temperature signals to determine the vertical flux from the advective-transport characteristics. Both of these methods have inherent limitations and uncertainties based on their estimation techniques and the accuracy of input parameters.

3. Flow and heat-transport parameters were manually calibrated in the 1DTempPro simulation with a preference for standard values for the lagoon bed sediment. These same parameter values were used for the VFLUX simulation. The similarity in magnitude of computed seepage fluxes in the two models helps validate the results but does not preclude other nonunique solutions, and the chosen input parameters have high uncertainty.

4. At locations that did not have a temperature sensor above the lagoon bed, it was necessary to use a linear estimator to represent the effects of the upper sensor, which was based on nearby locations that do have upper temperature sensors. If a distant location's linear estimator was substantially different than those at closer locations, it was omitted in preference to the closer location. This approach assumes that spatial variations are represented in the observed differences in linear estimators, but the data locations are too sparse for any certainty.

5. The lack of local groundwater-level data to determine the groundwater gradient to the lagoon makes it impossible to independently estimate flux direction and magnitude. Having such information available would substantially help constrain the results of the simulations.

6. Changes in the sediment-water interface bed elevation, primarily brought on by Hurricane Irma, alter the assumed temperature-sensor depths and confound the data collection assumptions. Small-scale sedimentation and erosion can cause similar but smaller changes in bed elevation at other times without the information existing to account for the effects on flux computations.

\section{Discussion}

Although the simulation results indicate substantial spatial variations in seepage flux in the study area, the distribution of measurement locations is quite sparse. More temperature-measurement locations would be needed to truly characterize the spatial heterogeneity of groundwater seepage flux into the lagoon. In addition, the general characteristics of the Eau Gallie study area described in this report may differ from those in other parts of the IRL. As mentioned earlier, the Eau Gallie study area consists mostly of fine sand, but the bottom of the lagoon at the other area where temperature data were collected, Rockledge, contains rock outcrops covered in most places by a layer of organic-rich sediment and aquatic vegetation. The simulations also indicated that substantial seepage flux exists even at the farthest measured offshore locations, 110 to $130 \mathrm{~m}$ offshore, so further investigation would be needed to determine the full extent of groundwater seepage to the lagoon.

The temporal fluctuations in simulated seepage show a similar pattern at different locations, indicating the driving factors have large spatial scales. This would be expected if precipitation, groundwater, and lagoon levels were important. The magnitude of the temporal fluctuation varies substantially between locations, and the hydraulic connectivity of the lagoon bed to nearshore groundwater may be an explanatory factor.

The 1DTempPro simulates a constant seepage flux and must be applied stepwise to simulate a varying seepage time series. As a result, 1DTempPro is more cumbersome to use than VFLUX for longer-term transient simulations. However, VFLUX has more difficulty determining the temperature amplitude signal at higher flux rates, which can cause the simulation to fail. These failures were periodic and varied from location to location, but the periods of highest seepage flux are of most interest to studies of flow and transport of nutrients. If VFLUX simulation failures obscure flux results in times of crucial interest, it would be possible to apply 1DTempPro at these times to avoid the problems inherent in VFLUX.

This study demonstrates that the application of heat-transport and flux modeling that utilizes heat as a tracer can be used to estimate seepage flux in the IRL. This indirect method can be applied to further measurements for different time periods and locations to develop a better estimate of the temporal and spatial distribution of seepage fluxes in the IRL. These results provide useful insight that can support studies of the mass balance of the lagoon and nutrient loading, and the technique can be applied to other locations where groundwater/surface-water exchange must be determined.

\section{Summary}

The U.S. Geological Survey, in cooperation with the St. Johns River Water Management District, conducted a study to examine water fluxes in two small study areas in the Indian 
River Lagoon in east-central Florida: one near Eau Gallie and the other near Rockledge. For this study, vertical arrays of temperature sensors were placed at multiple locations in the bed of Indian River Lagoon at the Eau Gallie study area to measure temperature time series in the vertical profile. These data were used in two numerical models, 1DTempPro and VFLUX, to estimate seepage flux rates into the lagoon. 1DTempPro uses an inverse-modeling approach to calibrate groundwater flux to the measured temperature time series. VFLUX isolates the fundamental frequency signal in the temperature data and utilizes the resulting amplitude and phase differences between sensor locations to determine vertical water flux. Both of these methods were applied to the temperature data collected at Eau Gallie. The 1DTempPro results were used to determine which pairs of sensors were best to use for the VFLUX computation of flux. Because some of the locations did not have a sensor placed in the surface water above the lagoon bed, which was found to be important in computing seepage flux, a linear-fit method using the deeper sensors was developed to estimate fluxes for those locations without a surface-water sensor.

Field measurements were made during two time periods, March 23 to April 28, 2017, and June 1 to November 3, 2017. The first time period was shorter than the second period, and it corresponded to the dry season, whereas the second longer period was wetter and included the landfall of Hurricane Irma on September 10, 2017. Simulating one location during the first, drier period using 1DTempPro helped determine reasonable seepage fluctuations and provided guidelines for choosing which temperature sensor pairs used in the VFLUX simulations would produce the best results. VFLUX simulations at the eight locations indicated seepage flux rates of less than 20 centimeters per day $(\mathrm{cm} / \mathrm{d})$ and substantial seepage flux out to a distance of at least 110 meters from shore. There seemed to be a large spatial variation in average seepage flux rates within 40 meters of shore, varying from about 3 to $20 \mathrm{~cm} / \mathrm{d}$.

When applying VFLUX to the June 1-November 3, 2017 data, the simulation technique failed completely at four locations and had periodic simulation failures at other locations. The most likely reason for these failures during the second simulation period was the higher magnitude and fluctuation of the seepage flux compared to the first simulation period; isolating the fundamental frequency signal (that is, diurnal temperature variation) in the temperature data is more difficult under these conditions than when seepage fluxes are small. However, useful partial or full simulations were achieved at six locations. The landfall of Hurricane Irma added further complexities, and analyses of the computed fluxes showed that the relationship between fluxes computed with the highest sensor in surface water and fluxes computed with lower sensor pairs changed markedly after the hurricane. It is likely that the hurricane storm surge changed the depths of the sensors relative to the lagoon bed. The simulated seepage flux time series before the hurricane is considered most reliable.
The June 1 to November 3, 2017, simulations yielded higher seepage flux rates than the March 24 to April 28, 2017 simulations, sometimes as great as $40 \mathrm{~cm} / \mathrm{d}$, and more than $60 \mathrm{~cm} / \mathrm{d}$ at one location. The seepage time series during the hurricane indicates a downward seepage flux as a result of the storm surge followed by upwelling from precipitation recharge inland. At one location, closest to shore, the upward seepage flux seems to have dominated and little downward flux was noted. The average seepage flux rates are as high as $25 \mathrm{~cm} / \mathrm{d}$ near the coast and are about $20 \mathrm{~cm} / \mathrm{d} 130$ meters offshore, substantially higher than during the March-April period.

\section{References Cited}

Anderson, M.P., 2005, Heat as a ground water tracer: Groundwater, v. 43, p. 951-968, accessed July 31, 2018, at https://doi.org/10.1111/j.1745-6584.2005.00052.x.

Arya, S.P., 2001, Introduction to micrometeorology: New York, Academic Press.

Barile, P.J., 2018, Widespread sewage pollution of the Indian River Lagoon system, Florida (USA) resolved by spatial analyses of macroalgal biogeochemistry: Marine Pollution Bulletin, v. 128, p. 557-574.

Bredehoeft, J.D., and Papadopulos, I.S., 1965, Rates of vertical groundwater movement estimated from the Earth's thermal profile: Water Resources Research, v. 1, no. 2, p. 325-328.

Briggs, M.A., Lautz, L.K., Buckley, S.F., and Lane, J.W., 2014, Practical limitations on the use of diurnal temperature signals to quantify groundwater upwelling: Journal of Hydrology, v. 519, accessed July 31, 2018, at https://doi.org/10.1016/j.jhydrol.2014.09.030.

Briggs M.A., Lautz, L.K., McKenzie, J.M., Gordon, R.P., and Hare, D.K., 2012, Using high-resolution distributed temperature sensing to quantify spatial and temporal variability in vertical hyporheic flux: Water Resources Research, v. 48, no. 2, 16 p.

Cardenas, M.B., 2010, Thermal skin effect of pipes in streambeds and its implications on groundwater flux estimation using diurnal temperature signals: Water Resources Research, v. 46, no. 1, 12 p.

Gordon, R.P., Lautz, L.K., Briggs, M.A., and McKenzie, J.M., 2012, Automated calculation of vertical pore-water flux from field temperature time series using the VFLUX method and computer program: Journal of Hydrology, v. $420-421$, p. $142-158$.

Hatch, C.E., Fisher, A.T., Revenaugh, J.S., Constantz, J., and Ruehl, C., 2006, Quantifying surface water-groundwater interactions using time series analysis of streambed thermal records-Method development: Water Resources Research, v. 42, W10410. 
Indian River Lagoon National Estuary Program, 2018, Annual Report 2017-Indian River Lagoon National Estuary Program: Accessed March 23, 2018, at http://www.irlcouncil.com/uploads/7/9/2/7/79276172/ annrept_final_2-26-18.pdf.

Irvine, D.J., Briggs, M.A., Lautz, L.K., Gordon, R.P., McKenzie, J.M, and Cartwright, I., 2017, Using diurnal temperature signals to infer vertical groundwater-surface water exchange: Groundwater, v. 55, no. 1, p. 10-26, accessed April 12, 2018, at https://onlinelibrary.wiley.com/ doi/epdf/10.1111/gwat.12459.

Keery, J., Binley, A., Crook, N., and Smith, J.W.N., 2007, Temporal and spatial variability of groundwater-surface water fluxes-Development and application of an analytical method using temperature time series: Journal of Hydrology, v. 336, p. 1-16.

Koch, F.W., Voytek, E.B., Day-Lewis, F.D., Healy, R., Briggs, M.A., Werkema, D., and Lane, J.W., Jr., 2016, 1DTempPro V2-New features for inferring groundwater/surface-water exchange: Groundwater, v. 54, no. 3, 6 p., accessed July 31, 2018, at https://doi.org/10.1111/gwat.12369.

Lapham, W.W., 1989, Use of temperature profiles beneath streams to determine rates of vertical ground-water flow and vertical hydraulic conductivity: U.S. Geological Survey Water-Supply Paper 2337.

Luce, C.H., Tonina, D., Garigilo, F., and Applebee, R., 2013, Solutions for the diurnally forced advection-diffusion equation to estimate bulk fluid velocity and diffusivity in streambeds from temperature time series: Water Resources Research, v. 49, p. 488-506.

McCallum, A.M., Andersen, M.S., Rau, G.C., and Acworth, R.I., 2012, A 1-D analytical method for estimating surface water-groundwater interactions and effective thermal diffusivity using temperature time series: Water Resources Research, v. 48, W11532.

Prinos, S.T., and Briggs, M.A, 2017, Temperature data collected in the Indian River Lagoon to evaluate groundwater seepage, Brevard County, Florida, 2017-2018: U.S. Geological Survey data release, accessed August 1, 2018, at https://doi.org/10.5066/F7VM4B41.

Rosenberry D.O., Briggs M.A., Delin, G., and Hare, D.K., 2016, Combined use of thermal methods and seepage meters to efficiently locate, quantify, and monitor focused groundwater discharge to a sand-bed stream: Water Resources Research, v. 52, no. 6, p. 4486-4503.
Scott, T., 1993, Geologic map of Brevard County, Florida: Florida Geological Survey, accessed March 23, 2018, at https://ngmdb.usgs.gov/Prodesc/proddesc_27373.htm.

St. Johns River Water Management District, 2007, Indian River Lagoon-An introduction to a national treasure: St. Johns River Water Management District report, 40 p., accessed April 19, 2018, at https://www.epa.gov/sites/production/files/2018-01/documents/58692_an_river_lagoon_ an_introduction_to_a_natural_treasure_2007.pdf.

St. Johns River Water Management District, 2018, Indian River Lagoon: St. Johns River Water Management District website, accessed February 9, 2018, at https://www.sjrwmd. $\mathrm{com} /$ waterways/indian-river-lagoon/facts/.

St. Johns River Water Management District, BethuneCookman University, Florida Atlantic University-Harbor Branch Oceanographic Institution, Florida Fish and Wildlife Conservation Commission, Florida Institute of Technology, Nova Southeastern University, Smithsonian Marine Station at Ft. Pierce, University of Florida, Seagrass Ecosystems Analysts, 2012, Indian River Lagoon 2011 superbloom plan of investigation: St. Johns River Water Management District report, accessed March 23, 2018, at https://www.sjrwmd. com/static/waterways/irl-technical//2011superbloom_investigationplan_June_2012.pdf.

Swain, E.D., 2018, Model data sets for 1DTempPro and VFLUX simulation experiments to determine groundwater seepage in the Indian River Lagoon, Florida: U.S. Geological Survey data release, https://doi.org/10.5066/ P9Q8JGAO.

Swarzenski, P.W., Martin, J.B., Cable, J.E., Lindenberg, M.K., Boynton, B., and Bowker, R., 2000, Quantifying submarine groundwater discharge to Indian River Lagoon, Florida: U.S. Geological Survey Open-File Report 00-492, 4 p., accessed April 13, 2018, at https://pubs.usgs.gov/ of/2000/0492/report.pdf.

Trefry, J.H. and Trocine, R.P., 2011, Metals in sediments and clams from the Indian River Lagoon, Florida - 2006-7 versus 1992: Florida Scientist, v. 74, p. 43-62.

U.S. Geological Survey, 2016, Anastasia Formation: U.S. Geological Survey website, accessed April 12, 2018, at https://mrdata.usgs.gov/geology/state/sgmc-unit. php?unit=FLPSa $\% 3 \mathrm{~B} 0$

Vogt, T., Schneider, P., Hahn-Woernle, L., and Cirpka, O.A., 2010, Estimation of seepage rates in a losing stream by means of fiber-optic high-resolution vertical temperature profiling: Journal of Hydrology, v. 380, p. 154-164. 
For more information about this publication, contact

Director, Caribbean-Florida Water Science Center

U.S. Geological Survey

4446 Pet Lane, Suite 108

Lutz, FL 33559

(813) 498-5000

For additional information visit

https://www2.usgs.gov/water/caribbeanflorida/index.html

Publishing support provided by

Lafayette Publishing Service Center 
